\title{
The Beneficial Root-Colonizing Fungus Mortierella hyalina Promotes the Aerial Growth of Arabidopsis and Activates Calcium-Dependent Responses That Restrict Alternaria brassicae-Induced Disease Development in Roots
}

\author{
Joy Michal Johnson, ${ }^{1}$ Anatoli Ludwig, ${ }^{1}$ Alexandra C. U. Furch, ${ }^{1}$ Axel Mithöfer, ${ }^{2,3}$ Sandra Scholz, ${ }^{1}$ \\ Michael Reichelt, ${ }^{4}$ and Ralf Oelmüller ${ }^{1, \dagger}$ \\ ${ }^{1}$ Matthias-Schleiden-Institute for Bioinformatics, Genetics and Molecular Botany, Department of Plant Physiology, Friedrich- \\ Schiller-University, Dornburger Str. 159, 07743 Jena, Germany; ${ }^{2}$ Department of Bioorganic Chemistry, Max Planck Institute for \\ Chemical Ecology; ${ }^{3}$ Research Group Plant Defense Physiology, Max Planck Institute for Chemical Ecology; ${ }^{4}$ Department of \\ Bioorganic Chemistry, Max Planck Institute for Chemical Ecology, Hans-Knöll-Straße 8, 07745 Jena, Germany
}

Accepted 17 September 2018.

The endophytic fungus Mortierella hyalina colonizes the roots of Arabidopsis thaliana and stimulates growth and biomass production of the aerial parts but not of roots. An exudate fraction from the fungus induces rapid and transient cytoplasmic $\mathrm{Ca}^{2+}$ elevation in the roots. The $\mathrm{Ca}^{2+}$ response does not require the well-characterized (co)receptors BAK1, CERK1, and FLS2 for pathogen-associated molecular patterns, and the $\mathrm{Ca}^{2+}$ channels GLR-2.4, GLR-2.5, and GLR-3.3 or the vacuolar TWO PORE CHANNEL1, which might be involved in cytoplasmic $\mathrm{Ca}^{2+}$ elevation. We isolated an ethyl-methanesulfonate-induced Arabidopsis mutant that is impaired in this $\mathrm{Ca}^{2+}$ response. The roots of the mutant are impaired in M. hyalina-mediated suppression of immune responses after Alternaria brassicae infection, i.e., jasmonate accumulation, generation of reactive oxygen species, as well as the activation of jasmonate-related defense genes. Furthermore, they are more colonized by $M$. hyalina than wild-type roots. We propose that the mutant gene product is involved in a $\mathrm{Ca}^{2+}$-dependent signaling pathway activated by $M$. hyalina to suppress immune responses in Arabidopsis roots.

The root-colonizing endophytic fungus Mortierella hyalina belongs to the order Mortierellales, the largest genus within the Mucoromycota (Benny 2009; Spatafora et al. 2016). The genus Mortierella is quite diverse and estimated to contain 100 to 170 species (Nagy et al. 2011). The members of this genus live as saprobes in soil on decaying organic material (Linnemann 1941), are globally distributed, and have been isolated from polar and equatorial regions, from lowlands to alpine areas (Linnemann 1958; Melo et al. 2014). The hyphae are hyaline

${ }^{\dagger}$ Corresponding author: R. Oelmüller; E-mail: ralf.oelmueller@uni-jena.de

Funding: This work was funded by the Deutsche Forschungsgemeinschaft (CRC1127).

*The $\boldsymbol{e}$-Xtra logo stands for "electronic extra" and indicates that one supplementary figure and one supplementary table are published online.

@ 2019 The American Phytopathological Society and form a coenocyte, which becomes irregularly septated when acquiring maturity (Tedersoo et al. 2014). The sporangiophores are mostly branched and do not form a columella (Zycha et al. 1969). Various members of order Mortierellales have been shown to dominate fungal communities in naturally occurring ecosystems (Uehling et al. 2017). Many Mortierella species can easily be cultured on synthetic media (Bonito et al. 2014) and have a garlic-like odor (Gams 1977), and the unique lipid metabolism of some Mortierella species makes them interesting for biotechnological applications (Kosa et al. 2018; Sakuradani 2010; Sakuradani and Shimizu 2009; Sakuradani et al. 2009, 2013). Furthermore, Mortierella elongata hosts the endophytic betaproteobacterium (Sato et al. 2010) Mycoavidus cysteinexigens FMR23-6 I-B1 (Ohshima et al. 2016). Uehling et al. (2017) showed that the fungal genome features a core set of primary metabolic pathways for degradation of simple carbohydrates and lipid biosynthesis, while the bacterial genome is reduced in size and function. The phylogenomic analyses suggest an ancient origin for $M$. elongata-Mycoavidus cysteinexigens symbiosis, most likely over 350 million years ago and concomitant with the terrestrialization of earth (Uehling et al. 2017).

Besides their saprophytic lifestyle, the rapidly growing fungi with multinucleated haploid mycelia are also able to form mutualistic mycorrhiza-like symbiosis with a broad spectrum of host species, ranging from trees to di- and monocots and mosses, and are found in association with macroalgae (Furbino et al. 2014). On poor soils, Mortierella spp. were often observed in association with the roots of trees, but the fungal association decreased with improved growth of the plants and composition of the soil, indicating that Mortierella is an early root colonizer. $M$. chlamydospora and $M$. indohii are mainly found on the root surface, but penetration of cortex cells and intercellular growth of the fungus was also observed, indicating a closer relation between both organisms (Ansell and Young 1982). Similar to mycorrhizal fungi, Mortierella spp. support phosphate uptake into the plants, which may participate in or cause the stimulation of biomass production of the host (Wang et al. 2011).

We found that $M$. hyalina hyphae colonize the roots of Arabidopsis thaliana, which resulted in substantial growth promotion of the aerial parts of the hosts. To investigate 
mechanisms and chemical mediators involved in the beneficial interaction, we focused on Arabidopsis. We describe that the fungus releases one or more compounds that control root colonization and pathogen infections by activating $\mathrm{Ca}^{2+}$-dependent innate immune responses in the roots.

\section{RESULTS}

\section{M. hyalina promotes plant growth.}

When Arabidopsis roots were cocultivated with M. hyalina on agar plates for four days, the hyphae started branching and were mainly found on the root surface in close contact with the root hairs (Fig. 1A and B). After 7 days of cocultivation, $M$. hyalina had successfully colonized the entire root and started to sporulate on the root surface (Fig. 1C). Penetration of the hyphae into the root cortex and sporulation inside the vascular system after 20 days occurred rarely (Fig. 1D). After 10 days of cocultivation, the roots were entirely surrounded by a fungal network. Already after 7 days of cocultivation, an increase in the sizes and biomasses of the aerial parts of the host but not of the roots can be detected (Fig. 2). The dry weights of $M$. hyalina-colonized roots were even lower than that of uncolonized control roots (Fig. 2C). The stimulatory effect on the performance of the aerial parts was also detectable during longer cocultivation periods, while stimulation of root growth was never observed. This differs from the results obtained with another beneficial endophytic fungus, Piriformospora indica (renamed: Serendipita indica [Weiß et al. 2016]), which promoted shoot and root growth (Peškan-Berghöfer et al. 2004).

\section{A cell-wall preparation $(C W P)$ and} exudate fraction from $M$. hyalina induced cytoplasmic $\mathrm{Ca}^{2+}$ elevation in Arabidopsis roots.

We have previously demonstrated that CWPs from the endophytic fungus $S$. indica (CWP-Si) (Vadassery et al. 2009) and the pathogenic fungus Alternaria brassicae (CWP-A $b$; Johnson et al. 2014) induce $\left[\mathrm{Ca}^{2+}\right]_{\text {cyt }}$ elevation in Arabidopsis and tobacco roots. This preparation was originally described by Anderson-Prouty and Albersheim (1975) and contains mainly nonproteinous compounds. It enriches mycelial cell-wall
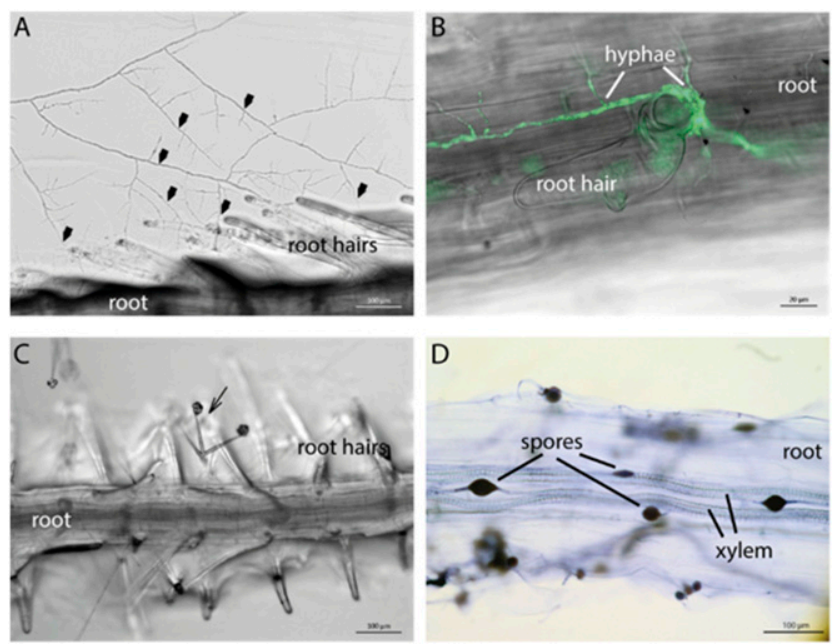

Fig. 1. Light microscopic images of the interaction of Mortierella hyalina hyphae with an Arabidopsis thaliana root. A, A main hypha (arrows) close to the root of Arabidopsis starts branching several times 4 days after cocultivation. B, The hyphae grow mainly on the root surface and around the root hairs. Hyphae are stained with Nile red. C, Sporulation of M. hyalina (arrow) at the root surface 7 days after cocultivation. D, The hyphae penetrate the root cortex after 20 days and spores were found between the xylem vessels. Stained with Chlorazol black E. material that elicits defense responses in the cotyledons and hypocotyls of bean seedlings and was used for further purification of a polysaccharide fraction with the fungal effector. The $\mathrm{Ca}^{2+}$ response induced by CWP-Si is required for growth promotion induced by the beneficial fungus $S$. indica (Johnson et al. 2018). Although $M$. hyalina did not promote root growth (Fig. 2), an almost identical $\mathrm{Ca}^{2+}$ response was observed with a CWP from this fungus (Fig. 3A). Under resting conditions, 18day-old transgenic apoaequorin-carrying Arabidopsis thaliana roots in the Col-0 background (pMAQ2) gave $\left[\mathrm{Ca}^{2+}\right]_{\text {cyt }}$ values of $66 \pm 0.9 \mathrm{nM}(n=24)$. A rapid and transient increase in the $\left[\mathrm{Ca}^{2+}\right]_{\text {cyt }}$ concentration is observed $40 \mathrm{~s}$ after the application of the CWP from M. hyalina (CWP-Mh). Discharge at the end of the experiment demonstrates that less than $5 \%$ of the reconstituted aequorin was consumed after the stimuli, which ensures that the amount of aequorin in the sample is not limiting for the $\mathrm{Ca}^{2+}$ signal. After a lag phase of 20 to $30 \mathrm{~s}$, the levels of $\left[\mathrm{Ca}^{2+}\right]_{\mathrm{cyt}}$ began to rise and reached a peak of approximately $550 \mathrm{nM}$ after 40 to $60 \mathrm{~s}$ (Fig. 3A). Subsequently, the $\mathrm{Ca}^{2+}$ levels steadily decreased and reached a plateau level (Fig. 3A). No $\left[\mathrm{Ca}^{2+}\right]_{\text {cyt }}$ elevation was observed with the water control (Fig. 3A). With the amounts of CWP-Mh used for these experiments, the magnitude of the $\left[\mathrm{Ca}^{2+}\right]_{\text {cyt }}$ response was dose-dependent (Fig. 3B).

As initial steps to identify the $\mathrm{Ca}^{2+}$-inducing activity in CWP-Mh, the proteins were removed by methanol precipitation. Since this had no effect on the $\mathrm{Ca}^{2+}$-inducing activity, proteins as chemical mediators could be excluded. The remaining CWP-Mh was then passed through a Roti-Spin Mini column with a molecular weight cut-off of $3 \mathrm{kDa}$ and was subjected to high-pressure liquid chromatography (HPLC) with a LC-18-DB column. This resulted in a single fraction with $\mathrm{Ca}^{2+}-$ inducing activity (not shown). Further purification was performed with an Asahipak NH2P-50 4E column, followed by an
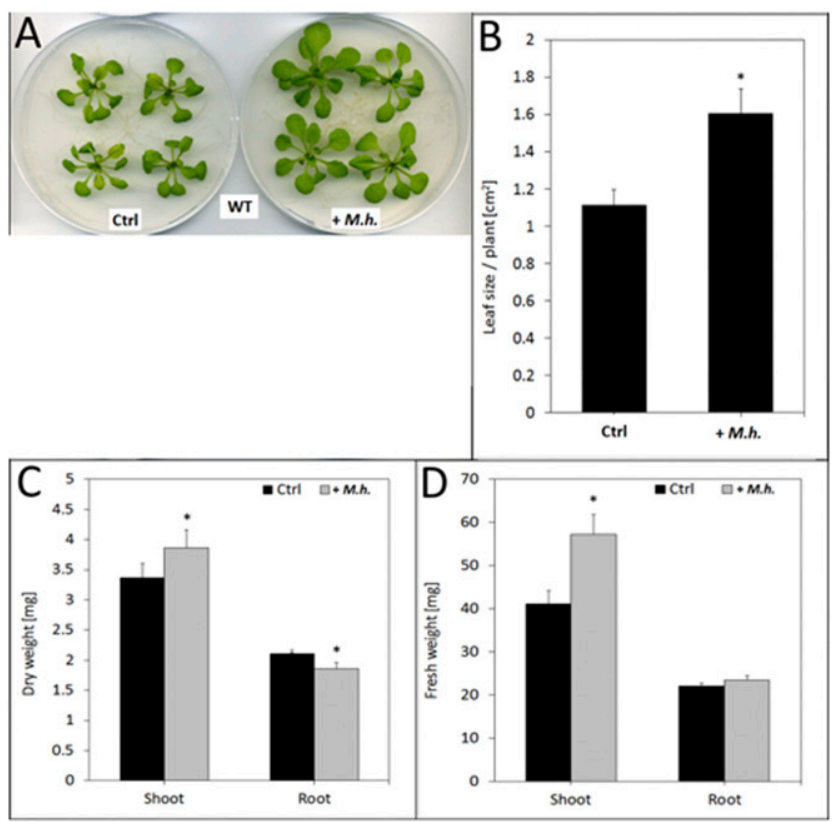

Fig. 2. Mortierella hyalina colonization of Arabidopsis roots promotes growth of the shoots but not roots. A, Two plates show Arabidopsis seedlings without $(\mathrm{Ctrl})$ and with $M$. hyalina $(+M . h$.) after 7 days of coculture. WT $=$ wild-type seedlings. B, Leaf area per plant of $M$. hyalina-colonized and not colonized WT Arabidopsis 7 days after cocultivation. $\mathbf{C}$ and D, Dry and fresh weights of $M$. hyalina-colonized WT Arabidopsis roots and shoots 7 days after cocultivation. All bars represent means with standard errors of four independent biological replicates. Asterisks indicate significant differences determined by $t$ test, with $P<0.05$. 
Acclaim C18 column and, finally, a C18 phenyl column. In each separation step, a single activity peak was detected. Since further purification was unsuccessful, this fraction, called fraction E, was used for further biochemical and physiological characterization.

The final fraction $\mathrm{E}$ induced $\left[\mathrm{Ca}^{2+}\right]_{\mathrm{cyt}}$ elevation in roots and less in shoots of Arabidopsis seedlings (Fig. 3C). Quantification of the activities demonstrates that the $\mathrm{Ca}^{2+}$ response in the shoots is more than three times lower than in the roots. A comparable organ-specific response pattern was observed for tobacco seedlings expressing the apoaequorin protein (not shown). Furthermore, CERK1, BAK1 and FS2, wellcharacterized (co)receptors of pathogen-associated molecular patterns, are not required for the $\mathrm{Ca}^{2+}$ response in Arabidopsis, since the corresponding knock-out lines in the aequorin background showed comparable $\mathrm{Ca}^{2+}$-inducing activity in response to the CWP-Mh as to the wild type (WT) (Fig. 3D). Finally, cellotriose from $S$. indica induces $\left[\mathrm{Ca}^{2+}\right]_{\text {cyt }}$ elevation in Arabidopsis roots (Johnson et al. 2018), and a mutant, cytoplasmic calcium elevation mutant of $S$. indica (cycam-Si), fails to respond to cellotriose (Johnson et al. 2018) (Fig. 3E, control). The response of cycam-Si roots to the CWP-Mh was also identical to the WT response, demonstrating that both responses are different (Fig. 3E). M. hyalina also releases one or more chemical mediators for $\mathrm{Ca}^{2+}$ induction into the growth medium, since a preparation from the growth medium, named soluble fraction, gives the same $\mathrm{Ca}^{2+}$ response as the CWP-Mh and the E fraction (Fig. 3F).

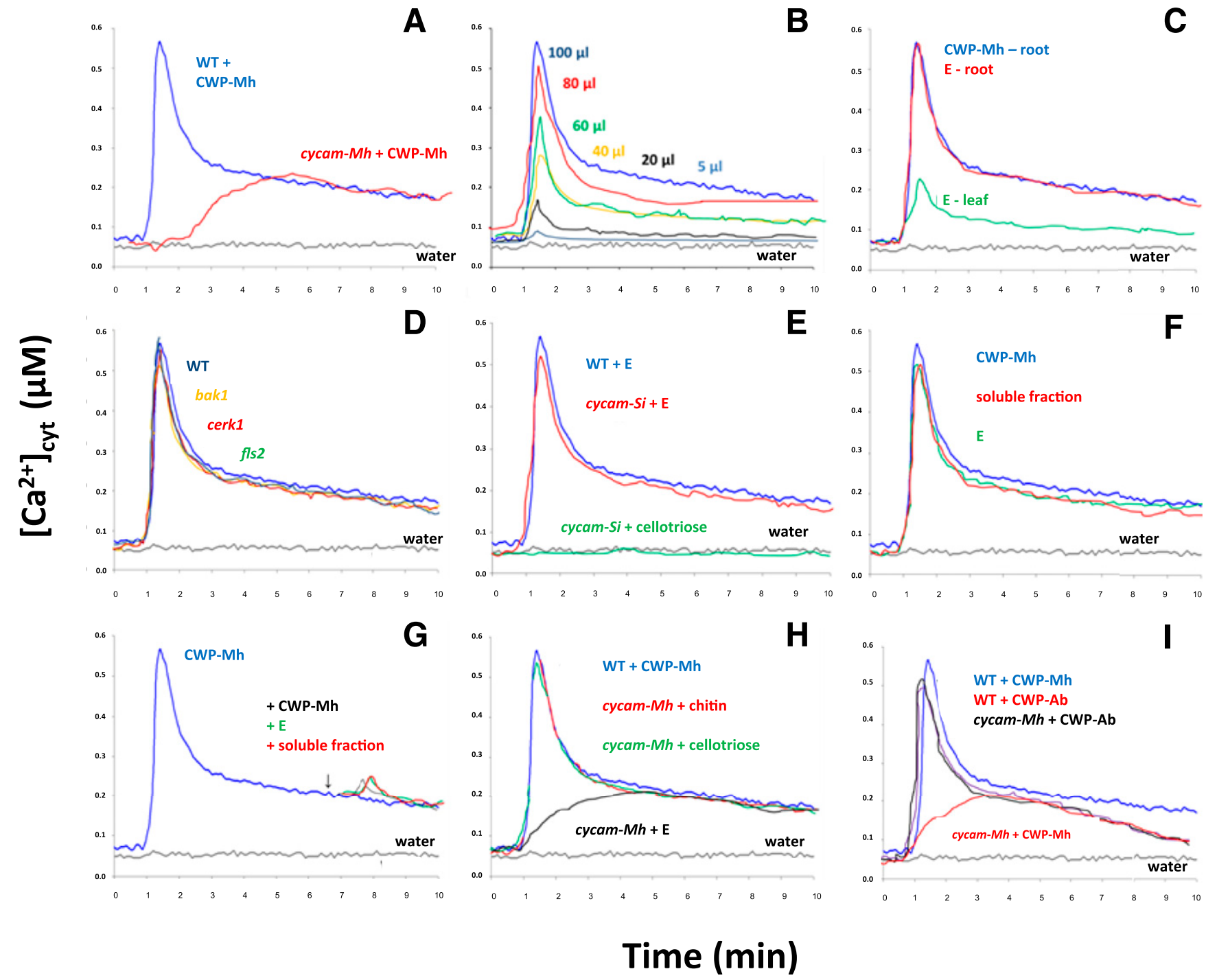

Fig. 3. Induction of $\left[\mathrm{Ca}^{2+}\right]_{c y t}$ elevation by Mortierella hyalina preparations in Arabidopsis roots and shoots. A, Cell-wall preparation from M. hyalina (CWP$\mathrm{Mh}, 100 \mu \mathrm{l})$ induces $\left[\mathrm{Ca}^{2+}\right]_{\mathrm{cyt}}$ elevation in the roots of Arabidopsis seedlings. The response of cytoplasmic calcium elevation mutant of M. hyalina (cycam-Mh) in roots lacks the peak induction after about $90 \mathrm{~s}$. B, Induction of $\left[\mathrm{Ca}^{2+}\right]_{\text {cyt }}$ elevation by CWP-Mh is dose-dependent. C, Further purification of the CWP resulted in fraction E, which gave the same $\left[\mathrm{Ca}^{2+}\right]_{\mathrm{cyt}}$ elevation response as the CWP in roots but less in shoots. D, Induction of $\left[\mathrm{Ca}{ }^{2+}\right]_{\mathrm{cyt}}$ elevation by the $\mathrm{E}$ fraction from M. hyalina in wild-type (WT) roots is identical to roots of cerkl, fls2, and bakl seedlings. E, The E fraction induces [Ca $\left.{ }^{2+}\right]_{\mathrm{cyt}}$ elevation in the roots of WT and cycam-Si (cytoplasmic calcium elevation mutant of Serendipita indica) seedlings. As control, no induction of $\left[\mathrm{Ca}^{2+}\right]_{\mathrm{cyt}}$ elevation is observed in the roots of cycam-Si seedlings by cellotriose. F, The CWP-Mh, E, and soluble fractions induce comparable $\left[\mathrm{Ca}^{2+}\right]_{\text {cyt }}$ elevation in WT roots. G, Application of the CWP-Mh, E, or soluble fractions $6.5 \mathrm{~min}$ after a first application of the CWP-Mh induce only little $\left[\mathrm{Ca}^{2+}\right]_{\text {cyt }}$ elevation. $\mathbf{H}$, Chitin or cellotriose induce a comparable $\left[\mathrm{Ca}^{2+}\right]_{\text {cyt }}$ elevation in cycam-Mh roots as the CWP in the WT roots, while the $\mathrm{E}$ fraction induces a $\left[\mathrm{Ca}^{2+}\right]_{\text {cyt }}$ elevation response that lacks the first $\left[\mathrm{Ca}^{2+}\right]_{\text {cyt }}$ peak. I, CWPs from M. hyalina and Alternaria brassicae (CWP-Ab) induce comparable $\mathrm{Ca}^{2+}$ responses in WT roots, while the CWP-Mh induces a $\mathrm{Ca}^{2+}$ response in cycam-Mh roots that lack the initial peak observed after $90 \mathrm{~s}$ in WT roots. The cycam-Mh roots show a Ca ${ }^{2+}$ response to the CWP-Ab that resembles that of WT roots. All graphs are representative for more than 10 independent replicates. All graphs show the response of WT roots to water, which was used as control, and the response to the CWP-Mh (except E). 
Initial studies suggest that perception of the chemical mediator from $M$. hyalina might be receptor-mediated. The $\mathrm{Ca}^{2+}$. inducing activity is severely reduced when the chemical mediators (applied as CWP-Mh, E, or soluble faction) are applied again $6.5 \mathrm{~min}$ after a first application, suggesting a refractory behavior for the response (Fig. 3G). Combinations of applications of the CWP-Mh, E, and soluble fractions, applied either as first or second stimuli, showed refractory behavior for all second applications (Fig. 3G, only shown for CWP-Mh as first stimulus). The results indicate that $M$. hyalina secretes one or more chemical mediators responsible for the $\mathrm{Ca}^{2+}$ response.

\section{Identification of an Arabidopsis mutant impaired in the stimulation of cytoplasmic $\mathrm{Ca}^{2+}$ elevation in response to the $M$. hyalina preparation.}

A previously described (Johnson et al. 2014) and newly generated ethylmethane sulphonate mutant populations were screened for Arabidopsis mutants that did not respond to the CWP-Mh. Among 104,000 individual plants that were screened for altered $\mathrm{Ca}^{2+}$ responses of the roots to the CWP-Mh, one candidate, named cytoplasmic calcium elevation mutant of $M$. hyalina (cycam-Mh), was investigated in more detail. This line was selected because application of the CWP-Mh (or E fraction) induced $\left[\mathrm{Ca}^{2+}\right]_{\text {cyt }}$ elevation in cycam-Mh roots, but the

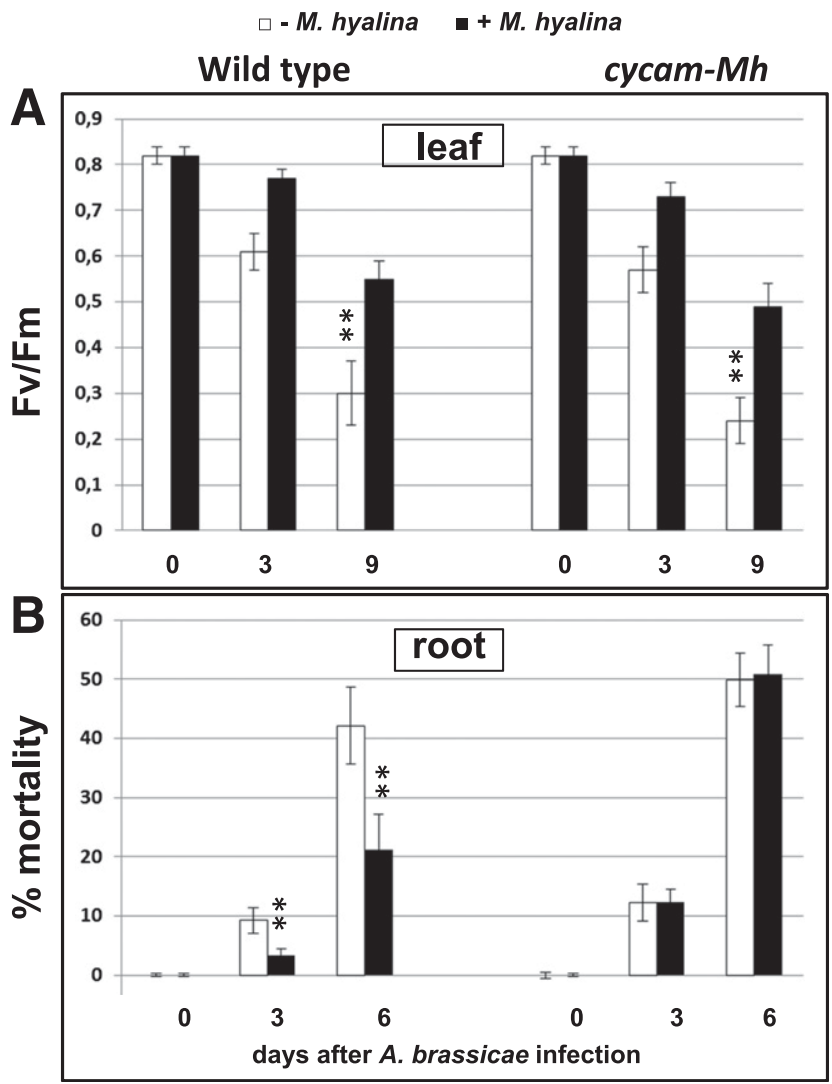

Fig. 4. Mortierella hyalina confers tolerance to Alternaria brassicae infections in wild-type (WT) and cytoplasmic calcium elevation mutant of $M$. hyalina (cycam-Mh) leaves but not in cycam-Mh roots. A, Leaves of WT or cycam-Mh seedlings, either mock-treated or pretreated with M. hyalina, were infected with $A$. brassicae spores and the fitness of the seedlings was measured as the efficiency of the electron transport through photosystem II (Fv/Fm) for 9 days. B, A. brassicae spores were applied to roots. After 0, 3 or 6 days, the roots were surface-sterilized, the seedlings were transferred to pots and were cultivated in a greenhouse for 30 days, before determination of the percent mortality. Bars represent means with standard errors of four independent biological replicates with 100 (top) and 25 (bottom) plants each. Asterisks indicate significant differences determined by $t$ test, with $P<0.05$. profile lacked the initial peak observed after $90 \mathrm{~s}$ (Fig. 3A and $\mathrm{H})$. Approximately 4 to $5 \mathrm{~min}$ after the elicitor treatment, the $\mathrm{Ca}^{2+}$ level reached the plateau that was also observed for the WT. Chitin and cellotriose, the chemical mediator responsible for the $\mathrm{Ca}^{2+}$ response induced by $S$. indica (Johnson et al. 2018), induced the same $\mathrm{Ca}^{2+}$ responses as in the WT (Fig. 3H). Also, a CWP from A. brassicae (CWP-Ab) (Johnson et al. 2014) induced a $\mathrm{Ca}^{2+}$ response in the cycam-Mh mutant that was identical to the response of the WT (Fig. 3I). When cycam$M h$ was backcrossed to WT (Col-0) or WT (La), $\left[\mathrm{Ca}^{2+}\right]_{\text {cyt }}$ elevation to the chemical mediator was restored in about $25 \%$ of $\mathrm{F}_{2}$ progenies, indicating that the mutation is recessive.

When kept on agar plates or on soil in the greenhouse, cycam-Mh did not show any visible phenotype. Interestingly, cocultivation of the mutant with $M$. hyalina also resulted in growth stimulation of the aerial parts (Supplementary Fig. S1) while no growth response was observed for the roots, as in the WT (fresh weight increase of aerial parts: WT, $31.2 \% \pm 4.2 \%$ and cycam-Mh, 34.4\% $\pm 3.9 \%$; fresh weight increase of the roots: WT, $0.2 \% \pm 0.2 \%$ and cycam-Mh, $-0.1 \% \pm 0.3 \% ; n=16$ ). Apparently, the lack of the $\mathrm{Ca}^{2+}$ peak in response to the CWPMh did not affect stimulation of growth of the aerial parts by the fungus.

\section{M. hyalina confers tolerance to $A$. brassicae infections in WT but not cycam-Mh roots.}

The leaves of $M$. hyalina-colonized seedlings were more resistant to infections with spores from the necrotrophic fungus A. brassicae than the leaves of uncolonized control seedlings. For this experiment, the roots were cocultivated with $M$. hyalina for 3 days before A. brassicae spores were applied to the leaves. The disease development was measured as decrease in the Fv/Fm values, representing the efficiency of the photosynthetic electron transfer through photosystem II. Without $M$. hyalina precolonization, the first disease symptoms in the infected leaves were detected 3 days after infection (dai). At 6 dai, the Fv/Fm value was dramatically decreased (Fig. 4, leaf). For $M$. hyalina-colonized seedlings, a visible retardation of the disease development was observed and the Fv/Fm values were higher than in the uncolonized control (Fig. 4, leaf). The more efficient electron transport efficiency of photosystem II in $M$. hyalina-colonized seedlings demonstrates that the fungus protects the leaves against $A$. brassicae infection. Interestingly, the same result was obtained for the cycam-Mh mutant, and the $\mathrm{Fv} / \mathrm{Fm}$ values were not significantly different from those for the WT seedlings (Fig. 4, leaf). These results were further supported by determination of the mortality rates 9 days after leaf infection; $54.8 \% \pm 6.1 \%(n=8)$ of the WT and $55.6 \% \pm 5.2 \%$ $(n=8)$ of the cycam-Mh seedlings were dead, while the mortality rates for WT and cycam-Mh seedlings that were precolonized by M. hyalina were reduced to $34.4 \% \pm 5.9 \%(n=8)$ and $32.4 \%$ $\pm 3.8 \%(n=8)$, respectively. Apparently, the mutation in cycam-Mh has little or no effect on the progression of disease development in the leaves (Fig. 4, leaf).

A quite different picture emerged from pathogen infection assays at the roots. To quantify the disease effects induced by $A$. brassicae, the roots of $M$. hyalina-colonized and uncolonized WT and cycam- $M h$ seedlings were inoculated with the pathogen. At 3 dai, the roots were surface-sterilized, the seedlings were transferred to pots, and the percent survival was assayed after 30 days in the greenhouse. Surface sterilization should prevent fungal effects after transfer to soil. When the roots of WT seedlings were infected with the pathogen for 6 days, $42.1 \% \pm 6.5 \%(n=8)$ of the WT seedlings did not recover. The presence of $M$. hyalina reduced the lethality rate to $21.2 \% \pm 5.9 \%(n=8)$ (Fig. 4, root). Thus, M. hyalina protects the roots of WT seedlings against $A$. brassicae infection. For 
cycam-Mh, the protective function of $M$. hyalina was no longer detectable, and the recovery rate 6 dai with $A$. brassicae spores was the same with and without $M$. hyalina pretreatment (no pretreatment, $49.6 \% \pm 4.5 \%$; with pretreatment, $50.9 \% \pm 4.5 \%$ ) (Fig. 4, root). Thus, the mutant roots but not the leaves were impaired in $M$. hyalina-induced resistance against $A$. brassicae infection (Fig. 4).

On agar plates, we observed an approximately $30 \%$ growth inhibition of $M$. hyalina when A. brassicae was present on the same plate, while $A$. brassicae growth was barely inhibited by M. hyalina (Fig. 5A). To test whether the mutation has an effect on the colonization by the two fungi, WT and cycam-Mh roots were first infected by $M$. hyalina or A. brassicae alone (Fig. 5B). No significant difference between the colonization of either ecotype could be detected by qPCR analyses when the roots were either inoculated with $M$. hyalina alone (0 to 9 days) or with $A$. brassicae alone (0 to 6 days) (Fig. 5B). Longer exposure of the roots to the pathogen did not give meaningful results because the disease symptoms were too severe. Figure 5C shows growth of the two fungi when they are growing together in the same roots. A. brassicae spores were applied to WT or mutant roots that were precolonized with $M$. hyalina for 3 days. Under these conditions, A. brassicae propagated faster in the cycam-Mh roots than in WT roots (Fig. 5C). This suggests that the mutation allows faster disease development and pathogen growth in A. brassicae-infected cycam-Mh roots than in WT roots. It is worth noting that, during the analyzed experimental period, M. hyalina colonization is not significantly different in WT and mutant roots, neither when growing alone (Fig. 5B) nor together with A. brassicae (Fig. 5C) (discussed below).

The cycam-Mh mutation restricts defense-gene activation.

Since $M$. hyalina pretreatment restricted A. brassicae growth in WT but not cycam-Mh roots, we tested how the fungus influences the plant defense machinery upon pathogen infection
A

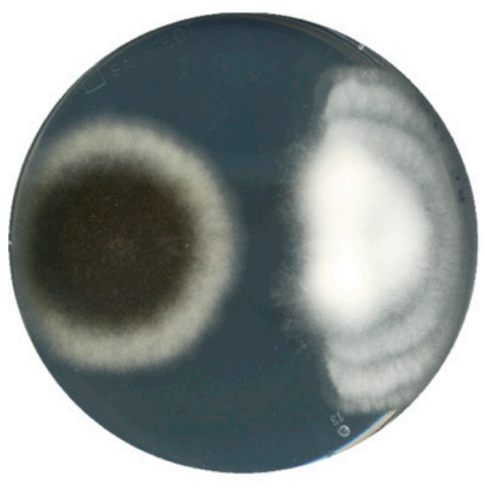

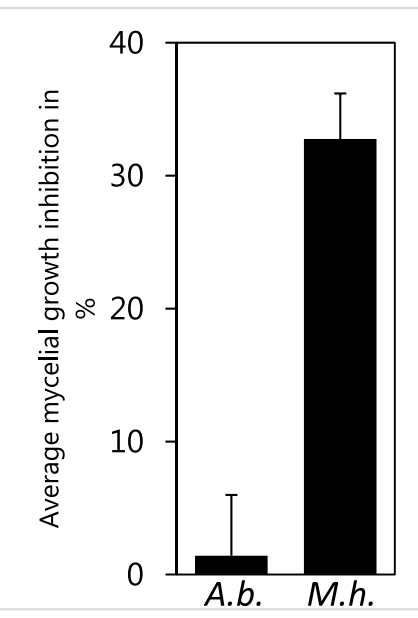

B

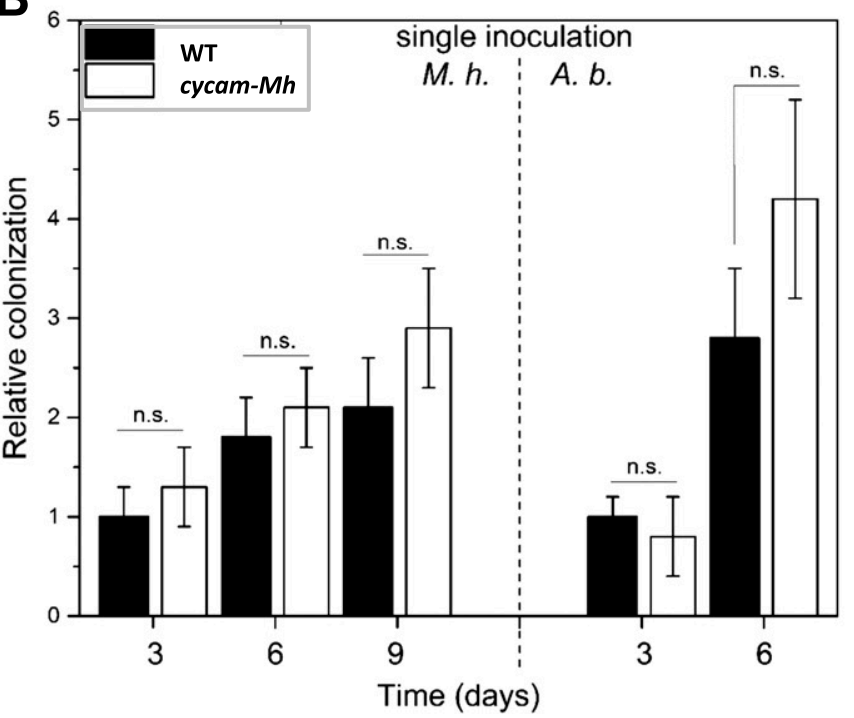

C

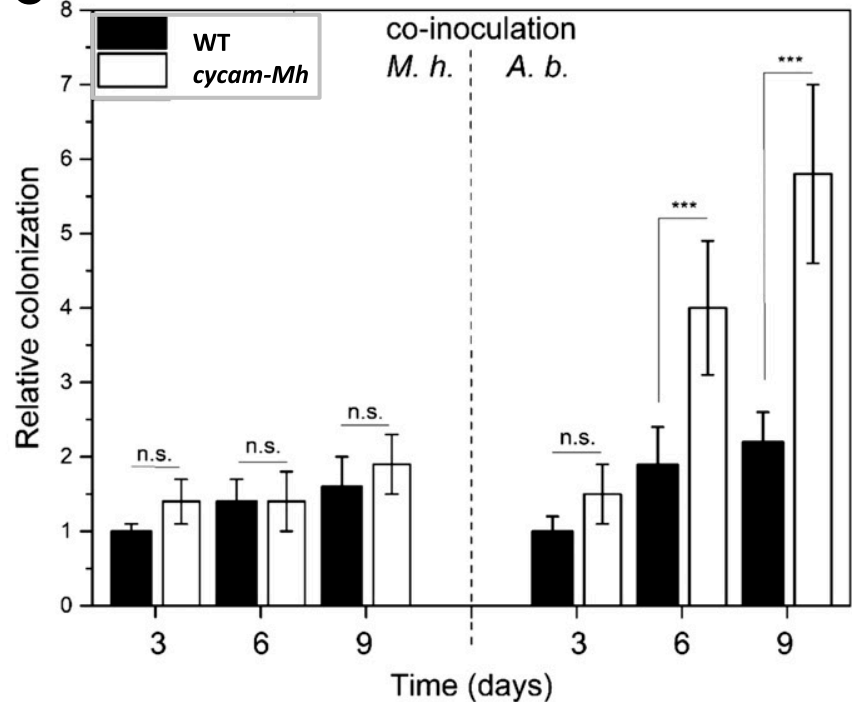

Fig. 5. Disease development of Mortierella hyalina-pretreated or mock-treated wild-type (WT) or cytoplasmic calcium elevation mutant of M. hyalina (cycam$M h$ ) seedlings after Alternaria brassicae infection. A, The picture shows growth of A. brassicae (black) and $M$. hyalina (white) on one agar plate. The graph shows percent growth inhibition (after 7 days) of both fungi when they are cultivated together on one agar plate compared with their growth alone. Based on three experiments, bars represent standard errors (SEs). B, The colonization of WT and cycam-Mh seedlings after infection with either $M$. hyalina alone or $A$. brassicae alone. The value for WT roots 3 days after colonization was set as 1.0 and all other values are expressed relative to it. n.s. $=$ not significant. $\mathbf{C}$, The colonization rate of WT and cycam-Mh roots of seedlings that were pretreated for 3 days with $M$. hyalina before application of A. brassicae spores. The amounts of both fungal tissue in the same root were determined 3, 6, and 9 days after $A$. brassicae infection. Based on eight independent experiments with 20 seedlings each, bars represent SEs. Asterisks indicate significant differences determined by $t$ test, with $P<0.05$. 
in the two plant genotypes. The roots of WT or cycam-Mh seedlings, pretreated with $M$. hyalina or not for 3 days, were harvested $24 \mathrm{~h}$ after $A$. brassicae infection (or no infection), and the amounts of phytohormones, reactive oxygen species (ROS) and expression levels of selected defense genes were assayed for the eight conditions (Table 1). In WT roots, A. brassicae induced jasmonic acid (JA) and JA-isoleucine (Ile) accumulation, the production of ROS, as well as the expression of the JAresponsive defense genes $P D F 1.2$, VSP2, and JAR1, while the accumulation of salicylic acid (SA) and of the mRNAs for the SA-responsive gene $P R 1$ were repressed. Pretreatment with $M$. hyalina severely reduced the effects induced by A. brassicae. Thus, the pathogen-induced jasmonate-based defense responses are reduced and the SA responses are less repressed in the $M$. hyalina-pretreated roots. The abscisic acid (ABA) level and the mRNA levels for the ABA-responsive genes $R d 29 A, R A B 18$, and JAM1 did not respond to the fungal treatments. The results are consistent with previously described systems in which beneficial root-colonizing microbes repress plant immune responses. In the cycam-Mh mutant, the $M$. hyalina pretreatment did not inhibit the A. brassicaeinduced alterations, and $M$. hyalina-pretreated and notpretreated roots showed the same response pattern to the pathogen. These results suggest that the $\mathrm{Ca}^{2+}$ response induced by exudated chemical mediators from $M$. hyalina is required to restrict A. brassicae-induced jasmonate responses in Arabidopsis roots.

To test whether cycam-Mh is specific for the M. hyalina compound, we compared the responses in the WT and cycam$M h$ roots with those induced by chitin and cellotriose from the beneficial fungus $S$. indica. Figure 3 shows that one or more chemical mediators secreted from $M$. hyalina induce cytoplasmic $\mathrm{Ca}^{2+}$ elevation in WT but not fully in the cycam-Mh mutant, while the $\mathrm{Ca}^{2+}$ response to chitin and cellotriose is the same in both genotypes (WT and cycam-Mh). The same holds true for the accumulation of ROS and stimulation of JA-responsive defense genes in WT and cycam-Mh roots (Table 2). Thus, it appears that the cycam-Mh mutation is specific for the one or more exudated compounds from M. hyalina.

\section{Long exposure of the cycam-Mh mutant}

\section{to $M$. hyalina or $S$. indica results in overcolonization.}

The experiments shown in Figure 4 demonstrate that short time exposure of the cycam-Mh mutant to $M$. hyalina results in root colonization comparable to that of WT seedlings, although the mutant is impaired in the activation of immune responses (Table 1). Therefore, we checked how the mutant responds to long-term cocultivation with $M$. hyalina. Furthermore, $S$. indica was included in the study. After 4 weeks on agar in jars, the roots of WT and cycam-Mh plants were harvested and were analyzed by qPCR for root colonization. Table 3 demonstrates that more than twice as much DNA of both fungi is found in cycam-Mh roots compared with WT roots. Thus, the impaired immune response in the mutant allows more root colonization by $M$. hyalina and $S$. indica after longer cocultivation periods. As known from other beneficial symbiotic interactions (Camehl et al. 2010; Sherameti et al. 2008), higher colonization of roots often results in loss of the benefits of the host plant. We observed an approximately $20 \%$ reduction of the root fresh weights for plants colonized by either of the two fungi. Also, the fresh weight of the aerial part of the $S$. indica-colonized cycam-Mh plants was reduced by approximately $20 \%$ compared with WT plants, while the aerial parts of the M. hyalinacolonized cycam-Mh plant was not reduced and not different from the WT. These results support our hypothesis that the mutation affects primarily the response of roots but not leaves to M. hyalina.
The cycam-Mh gene product affects multiple genes for $\mathrm{Ca}^{2+}$-dependent proteins and developmental programs.

Based on preliminary microarray data, we identified genes involved in root development or for $\mathrm{Ca}^{2+}$-binding proteins and that are regulated by either M. hyalina, A. brassicae, or the cycam-Mh mutation. These genes were used for qPCR analyses with $M$. hyalina-pretreated and not-pretreated WT and mutant roots after infection with the pathogen or mock treatment for 24 h. Three genes responded to M. hyalina but not to A. brassicae and CYCAM-Mh. SHORTROOT (SHR) is a GRAS transcription factor that participates in the specification of the endodermal cell fate (Benfey et al. 1993; Helariutta et al. 2000; Nakajima et al. 2001). CARPRICE (CPC) encodes an R3-type MYB transcription factor that is part of a protein complex involved in the determination of the root-hair cell fate (Bernhardt et al. 2005; Lee and Schiefelbein 1999; Tominaga et al. 2007; Wada et al. 1997). The mRNA level is downregulated by $A$. brassicae but remains high in M. hyalina-exposed WT and mutant roots. ARABIDOPSIS HISTIDINE PHOSPHOTRANSFER PROTEIN6 (AHP6) is a negative regulator of cytokinin signaling and the protein is involved in vascular tissue morphogenesis (Mähönen et al. 2006). The mRNA level is stimulated by M. hyalina and is strongly downregulated after A. brassicae infection, in both WT and mutant roots. Interestingly, the auxin-related genes AUXI (AUXIN RESISTANT1), PIN1 (PINFORMED1), PIN2, and LAX3 (LIKE-AUX3) are not responding to $M$. hyalina but are down-regulated upon $A$. brassicae infection. The first observation is consistent with the observation that $M$. hyalina does not stimulate root growth. RHD2/RBOHC and RRTF1 (REDOX-RESPONSIVE TRANSCRIPTION FACTOR1) (Matsuo et al. 2015) are encoded by ROS-responsive genes. They responded to both fungi in WT but not in cycam-Mh roots, consistent with the observation that both fungi do not stimulate ROS production in the mutant. Finally, we identified four genes for $\mathrm{Ca}^{2+}$-dependent proteins that responded only to M. hyalina in WT but not mutant roots (At3g47480, At3g03410, At5g23950, At3g60950). These genes are also induced by the $\mathrm{E}$ fraction from $M$. hyalina and cellotriose in WT but not in mutant roots and not by chitin. At3g47480 and At3g03410 encode uncharacterized $\mathrm{Ca}^{2+}$-binding EF-hand proteins, At5g23950 an uncharacterized $\mathrm{Ca}^{2+}$-dependent lipid-binding protein, and At3g60950 a $\mathrm{C} 2 \mathrm{Ca}^{2+} /$ lipid-binding protein with predicted endo-exonuclease or phosphatase activity. Apparently, the stimulation of their mRNA levels in WT requires cytoplasmic $\mathrm{Ca}^{2+}$ elevation induced by signals from $M$. hyalina or $S$. indica but not from A. brassicae or chitin. In the mutant, the response to the $\mathrm{E}$ fraction from $M$. hyalina is no longer detectable, while cellotriose from $S$. indica is still active. These examples demonstrate that the mutation and M. hyalina affect a specific subset of genes.

\section{DISCUSSION}

We describe $M$. hyalina as a novel root-colonizing endophyte that confers benefits to the model plant Arabidopsis (Fig. 2). As described for other root-colonizing microbes, we observed a rapid increase in cytoplasmic $\mathrm{Ca}^{2+}$ elevation in the host roots (Fig. 3). A mutant impaired in the $\mathrm{Ca}^{2+}$ response restricts jasmonate-dependent immune responses in A. brassicaeinfected Arabidopsis roots (Table 1). The $\mathrm{Ca}^{2+}$ response controls the plant immune response after pathogen infection and allows better survival of the host (Fig. 4). Since a lower level of defense in the presence of $M$. hyalina allows better performance of the A. brassicae-infected plants, control of the disease development does not require the fully activated defense machinery induced by the necrotroph. The $M$. hyalina-induced $\mathrm{Ca}^{2+}$ response differs from those induced by defense-activating pathogen-associated molecular patterns and from cellotriose of 
Table 1. Amounts of phytohormones, reactive oxygen species (ROS), and mRNA levels in Arabidopsis wild-type (WT) and cycam-Mh roots ${ }^{\mathrm{a}}$

\begin{tabular}{|c|c|c|c|c|}
\hline Phytohormones, ROS, genes & -M. hyaline $-A$. brassicae & + M. hyaline - A. brassicae & - M. hyaline + A. brassicae & + M. hyaline + A. brassicae \\
\hline \multicolumn{5}{|l|}{ WT } \\
\hline JA (ng/g fresh weight) & $4 \pm 1$ & $10 \pm 3$ & $168 \pm 10 * *$ & $82 \pm 7$ \\
\hline JA-Ile (ng/g fresh weight) & $0.96 \pm 0.03$ & $0.86 \pm 0.03$ & $1.22 \pm 0.02 *$ & $1.01 \pm 0.04$ \\
\hline cis-OPDA (ng/g fresh weight) & $12 \pm 2$ & $14 \pm 4$ & $17 \pm 4$ & $23 \pm 6^{*}$ \\
\hline SA (ng/g fresh weight) & $278 \pm 11$ & $256 \pm 12$ & $222 \pm 10$ & $216 \pm 19$ \\
\hline $\mathrm{ABA}$ (ng/g fresh weight) & $1.8 \pm 0.4$ & $1.3 \pm 0.3^{*}$ & $2.2 \pm 0.4$ & $1.3 \pm 0.4^{*}$ \\
\hline ROS (luminescence, RLU) & $165 \pm 55$ & $123 \pm 32$ & $923 \pm 310^{* * *}$ & $234 \pm 88$ \\
\hline $\begin{array}{l}\text { JA-responsive PDF1.2 (relative mRNA } \\
\text { level) }\end{array}$ & $1.0 \pm 0.2$ & $0.4 \pm 0.1$ & $3.4 \pm 0.2 * *$ & $1.2 \pm 0.4$ \\
\hline $\begin{array}{l}\text { JA-responsive } V S P 2 \text { (relative mRNA } \\
\text { level) }\end{array}$ & $1.0 \pm 0.4$ & $0.5 \pm 0.2$ & $2.5 \pm 0.5^{* *}$ & $1.3 \pm 0.3$ \\
\hline $\begin{array}{l}\text { JA-responsive } J A R I \text { (relative mRNA } \\
\text { level) }\end{array}$ & $1.0 \pm 0.2$ & $0.3 \pm 0.3$ & $3.9 \pm 0.6^{* * *}$ & $1.6 \pm 0.5$ \\
\hline $\begin{array}{l}\text { SA-responsive } P R 1 \text { (relative mRNA } \\
\text { level) }\end{array}$ & $1.0 \pm 0.2$ & $0.9 \pm 0.2$ & $0.4 \pm 0.2 * *$ & $0.6 \pm 0.1^{*}$ \\
\hline $\begin{array}{l}\text { ABA-responsive } R d 29 A \text { (relative mRNA } \\
\text { level) }\end{array}$ & $1.0 \pm 0.3$ & $0.7 \pm 0.3$ & $0.8 \pm 0.3$ & $0.9 \pm 0.2$ \\
\hline $\begin{array}{l}\text { ABA-responsive } R A B 18 \text { (relative mRNA } \\
\text { level) }\end{array}$ & $1.0 \pm 0.2$ & $0.9 \pm 0.2$ & $1.1 \pm 0.3$ & $0.8 \pm 0.3$ \\
\hline $\begin{array}{l}\text { ABA-responsive } J A M 1 \text { (relative mRNA } \\
\text { level) }\end{array}$ & $1.0 \pm 0.4$ & $1.3 \pm 0.2$ & $0.8 \pm 0.3$ & $1.0 \pm 0.2$ \\
\hline SHR (relative mRNA level) & $1.0 \pm 0.1$ & $2.3 \pm 0.4 * *$ & $1.0 \pm 0.4$ & $2.2 \pm 0.2 * * *$ \\
\hline$C P C$ (relative mRNA level) & $1.0 \pm 0.3$ & $1.3 \pm 0.2$ & $0.3 \pm 0.1 * * *$ & $0.3 \pm 0.2 * * *$ \\
\hline AHP6 (relative mRNA level) & $1.0 \pm 0.3$ & $3.0 \pm 0.5$ & $0.2 \pm 0.2 * * *$ & $0.4 \pm 0.1 * * *$ \\
\hline AUX1 (relative mRNA level) & $1.0 \pm 0.2$ & $1.2 \pm 0.3$ & $0.6 \pm 0.1 * *$ & $0.8 \pm 0.1$ \\
\hline PIN1 (relative mRNA level) & $1.0 \pm 0.2$ & $1.1 \pm 0.3$ & $0.5 \pm 0.3^{* *}$ & $0.7 \pm 0.1$ \\
\hline PIN2 (relative mRNA level) & $1.0 \pm 0.3$ & $1.2 \pm 0.1$ & $0.6 \pm 0.2$ & $0.7 \pm 0.2 *$ \\
\hline$L A X 3$ (relative mRNA level) & $1.0 \pm 0.2$ & $1.0 \pm 0.2$ & $0.7 \pm 0.1^{*}$ & $0.7 \pm 0.1^{*}$ \\
\hline RHD2 (relative mRNA level) & $1.0 \pm 0.3$ & $1.9 \pm 0.4 * *$ & $1.8 \pm 0.3 * * *$ & $2.0 \pm 0.5^{* *}$ \\
\hline$R R T F 1$ (relative mRNA level) & $1.0 \pm 0.3$ & $2.5 \pm 0.4 * * *$ & $1.9 \pm 0.5 * *$ & $2.9 \pm 0.6 * * *$ \\
\hline At3g 47480 (relative mRNA level) & $1.0 \pm 0.2$ & $4.4 \pm 0.8 * * *$ & $1.4 \pm 0.3$ & $4.8 \pm 0.9^{* * *}$ \\
\hline At3g03410 (relative mRNA level) & $1.0 \pm 0.3$ & $6.4 \pm 0.8 * * *$ & $0.7 \pm 0.4$ & $5.4 \pm 0.8^{* * *}$ \\
\hline At $5 g 23950$ (relative mRNA level) & $1.0 \pm 0.1$ & $3.9 \pm 0.6^{* * *}$ & $1.4 \pm 0.4$ & $4.5 \pm 0.9 * * *$ \\
\hline A3g60950 (relative mRNA level) & $1.0 \pm 0.2$ & $5.4 \pm 1.3 * * *$ & $0.8 \pm 0.1$ & $4.4 \pm 0.9 * * *$ \\
\hline \multicolumn{5}{|l|}{ cycam $_{\mathrm{Mh}}$} \\
\hline JA (ng/g fresh weight) & $7 \pm 2$ & $14 \pm 6$ & $228 \pm 27 * * *$ & $215 \pm 38 * * *$ \\
\hline JA-Ile (ng/g fresh weight) & $1.33 \pm 0.12$ & $1.22 \pm 0.11$ & $1.09 \pm 0.04$ & $0.88 \pm 0.09$ \\
\hline cis-OPDA (ng/g fresh weight) & $9 \pm 1$ & $10 \pm 2$ & $11 \pm 3$ & $13 \pm 4$ \\
\hline $\mathrm{SA}$ (ng/g fresh weight) & $222 \pm 21$ & $265 \pm 24$ & $201 \pm 17$ & $244 \pm 25$ \\
\hline ABA (ng/g fresh weight) & $1.3 \pm 0.3$ & $2.2 \pm 0.4$ & $1.3 \pm 0.6$ & $1.5 \pm 0.5$ \\
\hline ROS (luminescence, RLU) & $145 \pm 47$ & $154 \pm 28$ & $1202 \pm 98 * *$ & $1141 \pm 126^{* *}$ \\
\hline $\begin{array}{l}\text { JA-responsive PDF1.2 (relative mRNA } \\
\text { level) }\end{array}$ & $1.0 \pm 0.3$ & $0.7 \pm 0.2$ & $3.1 \pm 0.9^{*}$ & $3.0 \pm 0.7^{*}$ \\
\hline $\begin{array}{l}\text { JA-responsive VSP2 (relative mRNA } \\
\text { level) }\end{array}$ & $1.0 \pm 0.3$ & $0.8 \pm 0.4$ & $3.2 \pm 0.5^{* *}$ & $2.7 \pm 0.5^{*}$ \\
\hline $\begin{array}{l}\text { JA-responsive JARl (relative mRNA } \\
\text { level) }\end{array}$ & $1.0 \pm 0.3$ & $0.8 \pm 0.1$ & $3.9 \pm 1.2^{*}$ & $3.2 \pm 1.2 *$ \\
\hline $\begin{array}{l}\text { SA-responsive } P R 1 \text { (relative mRNA } \\
\text { level) }\end{array}$ & $1.0 \pm 0.4$ & $1.4 \pm 0.3$ & $1.3 \pm 0.4$ & $1.1 \pm 0.3$ \\
\hline $\begin{array}{l}\text { ABA-responsive } R d 29 A \text { (relative mRNA } \\
\text { level) }\end{array}$ & $1.0 \pm 0.4$ & $1.3 \pm 0.1$ & $1.4 \pm 0.4$ & $1.1 \pm 0.3$ \\
\hline $\begin{array}{l}\text { ABA-responsive } R A B 18 \text { (relative mRNA } \\
\text { level) }\end{array}$ & $1.0 \pm 0.3$ & $1.0 \pm 0.2$ & $1.4 \pm 0.4$ & $1.1 \pm 0.1$ \\
\hline $\begin{array}{l}\text { ABA-responsive } J A M 1 \text { (relative mRNA } \\
\text { level) }\end{array}$ & $1.0 \pm 0.2$ & $1.2 \pm 0.3$ & $0.9 \pm 0.1$ & $1.4 \pm 0.4$ \\
\hline SHR (relative mRNA level) & $1.0 \pm 0.4$ & $2.0 \pm 0.3 * *$ & $0.8 \pm 0.3$ & $2.2 \pm 0.4 * *$ \\
\hline$C P C$ (relative mRNA level) & $1.0 \pm 0.3$ & $1.2 \pm 0.2$ & $0.2 \pm 0.1$ & $1.2 \pm 0.2$ \\
\hline AHP6 (relative mRNA level) & $1.0 \pm 0.2$ & $2.7 \pm 0.4 * * *$ & $0.1 \pm 0.1$ & $0.4 \pm 0.1$ \\
\hline AUX1 (relative mRNA level) & $1.0 \pm 0.1$ & $1.3 \pm 0.3$ & $0.4 \pm 0.3$ & $0.6 \pm 0.2$ \\
\hline PIN1 (relative mRNA level) & $1.0 \pm 0.2$ & $0.9 \pm 0.2$ & $0.6 \pm 0.1 * *$ & $0.6 \pm 0.3^{*}$ \\
\hline PIN2 (relative mRNA level) & $1.0 \pm 0.3$ & $1.2 \pm 0.2$ & $0.4 \pm 0.1 * * *$ & $0.5 \pm 0.1 *$ \\
\hline$L A X 3$ (relative mRNA level) & $1.0 \pm 0.1$ & $1.3 \pm 0.3$ & $0.5 \pm 0.2 * *$ & $0.7 \pm 0.2^{*}$ \\
\hline RHD2 (relative mRNA level) & $1.0 \pm 0.2$ & $0.7 \pm 0.3$ & $0.9 \pm 0.3$ & $1.3 \pm 0.4$ \\
\hline RRTF1 (relative mRNA level) & $1.0 \pm 0.3$ & $1.5 \pm 0.3$ & $1.5 \pm 0.5$ & $1.4 \pm 0.4$ \\
\hline At3g47480 (relative mRNA level) & $1.0 \pm 0.2$ & $1.4 \pm 0.3$ & $1.4 \pm 0.1$ & $1.2 \pm 0.4$ \\
\hline At3g03410 (relative mRNA level) & $1.0 \pm 0.2$ & $0.9 \pm 0.2$ & $1.0 \pm 0.1$ & $0.9 \pm 0.2$ \\
\hline At5g23950 (relative mRNA level) & $1.0 \pm 0.2$ & $1.1 \pm 0.3$ & $0.7 \pm 0.2$ & $1.1 \pm 0.2$ \\
\hline A3g60950 (relative mRNA level) & $1.0 \pm 0.4$ & $0.7 \pm 0.1$ & $0.9 \pm 0.1$ & $1.3 \pm 0.4$ \\
\hline
\end{tabular}

\footnotetext{
${ }^{a}$ Roots were pretreated (+ M. hyalina) or mock-treated (-M. hyalina) with Mortierella hyalina for 3 days. Then, an Alternaria brassicae spore suspension ( $+A$. brassicae) was applied to the roots for $24 \mathrm{~h}$, control plants were treated with water (-A. brassicae). The phytohormone data are based on five independent experiments, the ROS and mRNA data on six independent experiments. The mRNA data for the $-M$. hyalina $-A$. brassicae treatments were set as 1.0 and all other values are expressed relative to them. Errors represent standard errors. Asterisks indicate significant differences of the values compared with the -M. hyalina-A. brassicae treatment, as determined by Student's $t$ test (one asterisk [*] $P \leq 0.1$; two [**] $P \leq 0.01$; three [***] $P \leq 0.001$ ). JA-Ile $=$ jasmonic acid-isoleucine; $\mathrm{OPDA}=12$-oxophytodienoic acid; $\mathrm{SA}=$ salicylic acid; $\mathrm{ABA}=$ abscisic acid.
} 
the root-colonizing beneficial fungus $S$. indica, which monitors cello-oligomer concentrations in the environment (Fig. 3). We propose that the gene product restricts jasmonate-dependent innate immune responses activated by $A$. brassicae infection in Arabidopsis roots. Several plant-growth-promoting microbes downregulate immune responses in the roots of their hosts or repress microbe-associated molecular pattern (MAMP)triggered immune responses (Bastias et al. 2016; Brotman et al. 2013; Lahrmann et al. 2013; Lakshmanan et al. 2013; Mayer et al. 2017; Mechri et al. 2015; Pozo et al. 2015; Verhagen et al. 2004; Zuccaro et al. 2011). S. indica utilizes JA signaling in Arabidopsis roots to suppress early and late defense responses (Jacobs et al. 2011). Identification of the mutated CYCAM-Mh gene will be important for further analysis and the connection between $\mathrm{Ca}^{2+}$ and jasmonate signaling.

Beneficial microbes utilize different strategies to protect plants against pathogen infections. They can stimulate the plant defense machinery by activating systemic resistance mechanisms that prime the entire plant for enhanced defense against a broad range of pathogens and insect herbivores (Pieterse et al. 2014; Stein et al. 2008). These defense-stimulating processes often involve jasmonate- and ethylene-dependent signaling pathways (Fernández et al. 2014; Song et al. 2015; Van Wees et al. 2008). Among the processes that repress the pathogeninduced defense machinery are ROS-scavenging enzymes (García-Sánchez et al. 2014; Zhang and Franken. 2014). Control or overcoming of the plant immune responses is also important for root colonization (Ivashuta et al. 2005; Wang et al. 2012; Zamioudis and Pieterse 2012), and $\mathrm{Ca}^{2+}$ signaling is well-known to participate in mediating compatibility in biotrophic and beneficial interactions (Chen et al. 2015). The $\mathrm{Ca}^{2+}$ dependent immune suppression mechanism described here also controls root colonization by $M$. hyalina and $S$. indica (Table 3 ) and restricts defense responses activated by the necrotroph (Table 1). The Glomus interaradices effector protein SP7 suppresses ethylene-induced immune responses and promotes fungal biotrophy (Kloppholz et al. 2011), and the effector protein MiSSP7 of the mutualistic fungus Laccaria bioclor stabilizes the Populus JAZ6 protein and represses JAresponsive genes, thereby promoting mutualism (Plett et al. $2014 \mathrm{a}$ and b). Also, $S$. indica expresses many genes for secreted proteins that might function as immune-suppressive effector molecules (Akum et al. 2015; Zuccaro et al. 2011). These examples can be extended to plant growth-promoting rhizobacteria, in which secreted effector proteins not only repress host immune response but also determine host-range specificity (Yang et al. 2010). However, the M. hyalina-induced suppression of the immune response is not activated by one or more proteinous chemical mediators, since only small molecularweight molecules but no proteins or peptides were found in the $\mathrm{Ca}^{2+}$-inducing $\mathrm{E}$ fraction from the fungus. Nonproteinous chemical mediators inducing immune responses are wellcharacterized. Lipopolysaccharides are components of gramnegative bacteria and are composed of conserved lipid A, core oligosaccharide regions, and a long-chain polysaccharide (the $O$ antigen) that can have variable composition, length, and branching of its carbohydrate subunits. Plants sense the $\mathrm{O}$ antigen, core oligosaccharide, and lipid A (Bedini et al. 2005; Silipo et al. 2005; Ye and Murata 2016). Chitin is an insoluble polymer of $\beta$-1,4-linked $N$-acetylglucosamine and one of the major components of the fungal cell wall (Sánchez-Vallet et al. 2015). Chitin derivatives are lipochitooligosaccharide (LCO) nodulation (Nod) factors from the nitrogen-fixing rhizobacteria that are recognized by legumes and sulfated or nonsulfated LCO mycorrhiza (Myc) factors and other short nonimmunogenic chitin oligomers that are produced by arbuscular mychorriza ( Dénarié et al. 1996; Maillet et al. 2011; Walker et al. 2000). Chitin, Nod, and Myc factors activate cell-surface receptors with extracellular LysM domains (Limpens et al. 2015; SánchezVallet et al. 2015), and differences in LysM ectodomains allow the plant to discriminate chitin derivatives from mutualistic and pathogenic fungi (Broghammer et al. 2012; Maillet et al. 2011; Miyata et al. 2014; Wang et al. 2014). Mixtures of $\beta-1 \rightarrow 3$-linked glucans have been shown to induce stomatal

Table 2. Accumulation of reactive oxygen species (ROS) and mRNAs for JA-responsive genes in Arabidopsis wild-type (WT) and cycam $_{M h}$ roots in response to treatments with the fraction E from Mortierella hyalina, cellotriose, and chitin ${ }^{\mathrm{a}}$

\begin{tabular}{|c|c|c|c|c|c|c|}
\hline \multirow[b]{2}{*}{ ROS, genes } & \multicolumn{3}{|c|}{ WT } & \multicolumn{3}{|c|}{ cycam-Mh } \\
\hline & $\mathbf{E}$ fraction & Cellotriose & Chitin & E fraction & Cellotriose & Chitin \\
\hline ROS (luminescence, RLU) & $16.2 \pm 1.3$ & $4.4 \pm 0.4$ & $18.1 \pm 1.5$ & $1.2 \pm 0.1$ & $4.6 \pm 0.5$ & $19.0 \pm 1.2$ \\
\hline $\begin{array}{l}\text { JA-responsive PDF1.2 (relative mRNA } \\
\text { level) }\end{array}$ & $4.9 \pm 0.9$ & $2.2 \pm 0.4$ & $5.5 \pm 0.7$ & $1.2 \pm 0.3$ & $2.4 \pm 0.1$ & $5.3 \pm 0.7$ \\
\hline JA-responsive VSP2 (relative mRNA level) & $4.1 \pm 0.4$ & $2.3 \pm 0.3$ & $4.6 \pm 0.6$ & $1.1 \pm 0.1$ & $2.0 \pm 0.4$ & $4.2 \pm 0.6$ \\
\hline JA-responsive $J A R 1$ (relative mRNA level) & $3.5 \pm 0.5$ & $2.1 \pm 0.2$ & $4.4 \pm 0.6$ & $1.3 \pm 0.1$ & $2.2 \pm 0.1$ & $4.7 \pm 0.7$ \\
\hline At3g 47480 (relative mRNA level) & $4.9 \pm 1.0$ & $2.6 \pm 0.7$ & $0.8 \pm 0.2$ & $0.9 \pm 0.3$ & $2.8 \pm 0.5$ & $1.4 \pm 0.4$ \\
\hline At3g03410 (relative mRNA level) & $4.5 \pm 0.4$ & $4.1 \pm 0.8$ & $0.9 \pm 0.2$ & $1.2 \pm 0.1$ & $4.8 \pm 0.9$ & $0.8 \pm 0.1$ \\
\hline At5g23950 (relative mRNA level) & $5.1 \pm 0.9$ & $4.0 \pm 0.6$ & $1.4 \pm 0.3$ & $1.2 \pm 0.3$ & $3.8 \pm 0.5$ & $0.9 \pm 0.3$ \\
\hline A3g60950 (relative mRNA level) & $6.5 \pm 1.5$ & $5.9 \pm 0.8$ & $1.3 \pm 0.3$ & $1.0 \pm 0.1$ & $5.8 \pm 1.2$ & $0.8 \pm 0.2$ \\
\hline
\end{tabular}

a Responses 30 min after application to the roots. To allow comparison, the fractions with the chemical mediators were applied in concentrations that induced almost saturated responses (in detail: application of double the amount of the elicitor fractions resulted in less than $10 \%$ increase in the responses). Chitin: $50 \mu \mathrm{l}$ of $10 \mu \mathrm{M}$ in water; cellotriose: $50 \mu \mathrm{l}$ of $10 \mu \mathrm{M}$ in water; $50 \mu \mathrm{l}$ of fraction E from M. hyalina. The data show fold stimulation compared with untreated control roots, which were identical for WT and cycam-Mh. Based on six independent experiments, errors are standard errors.

Table 3. Effects of long-term cocultivation of wild-type (WT) and cycam $_{M h}$ plants with Mortierella hyalina or Serendipita indica

\begin{tabular}{|c|c|c|c|c|}
\hline \multirow[b]{2}{*}{ Colonization rate and fresh weights } & \multicolumn{2}{|c|}{ M. hyalina } & \multicolumn{2}{|c|}{ S. indica } \\
\hline & WT & cycam-Mh & WT & cycam-Mh \\
\hline Colonization rate [relative values] & $1.0 \pm 0.3$ & $2.7 \pm 0.8$ & $1.0 \pm 0.2$ & $2.4 \pm 0.7$ \\
\hline Root fresh weight $[\mathrm{mg} /$ seedling $]$ & $2.2 \pm 0.4$ & $1.6 \pm 0.5$ & $2.3 \pm 0.3$ & $1.7 \pm 0.6$ \\
\hline Fresh weight of aerial part [mg/seedling] & $10.1 \pm 1.0$ & $10.9 \pm 1.1$ & $10.2 \pm 0.7$ & $8.0 \pm 0.8$ \\
\hline
\end{tabular}


closure (Allègre et al. 2009; Fu et al. 2011). Elicitor preparations from baker's yeast mainly contain fungal cell-wall material, including mannan, $\beta-1 \rightarrow 3$-linked glucans, chitin, and glycopeptides, and have been widely used as a fungal MAMP to induce plant immune responses (Ye and Murata 2016). Oligogalacturonides are released from plant cell-wall pectin by pathogen-derived polygalacturonases that are perceived by the receptor-like kinase WAK1/2 (Benedetti et al. 2015; Brutus et al. 2010). Recently, cellooligomers were identified as novel chemical mediators in Arabidopsis that inform the cell about the alterations in and around the cell wall (Johnson et al. 2018; Oelmüller 2018; Souza et al. 2017). They can be of microbial and plant origin and represent novel invasion patterns (Cook et al. 2015). We could not detect any of these components in the $\mathrm{E}$ fraction from $M$. hyalina by mass spectrometry. Furthermore, genetic evidence excludes similarities with chitin, flg22, and cellooligomer signaling (Fig. 3). Identification of the chemical nature of the active compound will allow us to investigate the $\mathrm{Ca}^{2+}$-inducing activity in more detail.

The $\mathrm{Ca}^{2+}$ signatures of the cycam-Mh mutant after application of the stimuli from $M$. hyalina are interesting, since they only lack the initial increases observed for WT roots, while the plateau level is reached after approximately $4 \mathrm{~min}$ (Fig. 3A, H, and I). Almost all other mutants described so far are impaired in any increase in cytoplasmic $\mathrm{Ca}^{2+}$ levels in response to stimuli, e.g., chitin, flg22, or cellotriose (Johnson et al. 2011a, 2018; Ranf et al. 2015). Since the aequorin-based $\mathrm{Ca}^{2+}$ measurement only shows $\mathrm{Ca}^{2+}$ levels after integration over defined periods of time, the absence of any $\mathrm{Ca}^{2+}$ increase may indicate that the overall level in the cell does not change. The signature observed here suggests that the $\mathrm{Ca}^{2+}$ level increases in response to the $M$. hyalina stimulus but does not reach a threshold level required for the response. Again, identification of the mutated gene may provide more information.

This is the first report of disease inhibition by any Mortierella species. We demonstrate that $\mathrm{Ca}^{2+}$ is a crucial second messenger in mediating this response in Arabidopsis roots. It is important to mention that the $\mathrm{Ca}^{2+}$ response is only one mechanism by which $M$. hyalina promotes plant performance. For instance, only some of the analyzed root genes that respond to M. hyalina colonization depend on CYCAM-Mh (Table 2). Apparently, other chemical mediators or a physical contact between the two symbionts activate additional processes. Furthermore, the fungus also promotes growth of the aerial part of the cycam-Mh mutant (Fig. 2). Crucial players in this scenario could be volatiles. Many but not all Mortierella species release a quite unique bouquet of volatiles, which influence growth and resistance as well as expression, hormone, and metabolite patterns of their hosts (Gams 1977; R. Oelmüller unpublished). Furthermore, many Mortierella species harbor endophytic bacteria, some of which are interesting for scientific and evolutionary studies (Uehling et al. 2017), others might be relevant for agricultural applications. Finally, the unusual fatty acid composition produced by some of the Mortierella species (Zhang et al. 2018) might have an influence on plant performance. Therefore, the $M$. hyalina-Arabidopsis interaction represents an interesting model system to study beneficial root symbioses at different levels.

\section{MATERIALS AND METHODS}

Culturing and growth conditions of fungi and Arabidopsis.

Arabidopsis seedlings (12 days old, after 2 days of stratification and 10 days in a growth chamber under long-day conditions and light from the top [60 to $70 \mu \mathrm{M} \mathrm{m}^{-2} \mathrm{~s}^{-1}, 16 \mathrm{~h}$ of light and $8 \mathrm{~h}$ of dark at $22^{\circ} \mathrm{C}$ ) ) were transferred from Murashige-
Skoog plates to plates with solid plant nutrient medium and a nylon membrane (mesh size $70 \mu \mathrm{m}$ ), as described previously (Camehl et al. 2011). Seedlings were then grown for an additional $24 \mathrm{~h}$ under long-day conditions and light from the top $\left(80 \mu \mathrm{M} \mathrm{m}^{-2} \mathrm{~s}^{-1}, 16 \mathrm{~h}\right.$ of light and $8 \mathrm{~h}$ of dark) at $22^{\circ} \mathrm{C}$. These seedlings were then used for the different experiments, either transfer to fresh plates with and without fungi or incubation of the roots with elicitors. For the experiments in jars (Weck Company, 500-ml glass jar), the seedlings were transferred to nylon membranes with a hyphal lawn of $M$. hyalina or $S$. indica (precultivated for 7 days), were then removed from the membrane and were transferred to jars for 4 weeks under long-day conditions (four seedlings per jar).

For elicitor application, the roots were soaked in a solution containing the chemical mediators (cellotriose or chitin or the preparations from $M$. hyalina, discussed below); autoclaved $\mathrm{H}_{2} \mathrm{O}$ was used as control. The plates with the seedlings were then transferred back to long-day conditions, before the roots were harvested after the treatments described in the text.

Transgenic Arabidopsis thaliana expressing cytosolic apoaequorin $\left(\mathrm{Aeq}^{\mathrm{cyt}}\right.$ ) in Col-0 background (pMAQ2) was a gift from M. Knight (Knight et al. 1991; Polisensky and Braam 1996). Mutagenesis was performed using $0.2 \%$ ethyl-methane sulfonate (wt/vol).

The A. brassicae (FSU-3951) and M. hyalina (FSU-509) strains were obtained from Jena Microbial Resource Center (Jena, Germany). For physiological experiments, M. hyalina was cultured and maintained on Kaefer medium (KM), pH 6.5, as described by Johnson et al. (2011b). A. brassicae was grown on potato dextrose agar medium (pH 6.5 to 6.7 ) at $20 \pm 1^{\circ} \mathrm{C}$ in a temperature-controlled chamber under a 12-h light and dark cycle and $75 \%$ relative humidity for 2 weeks (Johnson et al. 2018). The beneficial fungus was inoculated to Arabidopsis seedlings and reisolated from the infected tissues every 6 months (Johnson et al. 2013).

For the preparation of the cell-wall extract from M. hyalina, $S$. indica, and $A$. brassicae, the fungi were grown on KM broth for 18 days at a temperature of 22 to $24^{\circ} \mathrm{C}$ in darkness, on a horizontal rotating shaker, at 50 rounds per min (Johnson et al. 2011b; Vadassery et al. 2009). The soluble fractions were prepared as described in Johnson et al. (2018).

The $A$. brassicae spore suspensions were obtained from 3-weekold fungal plates. The mycelium was transferred to $5 \mathrm{ml}$ of distilled water. After two filtrations through a sterile nylon membrane, the spore concentration was adjusted to $10^{6}$ spores per milliliter.

\section{Root colonization.}

Roots from plates were harvested and were washed intensively with distilled water before RNA extraction. $A$. brassicae, $M$. hyalina, and $S$. indica were monitored by qPCR analyses (Supplementary Table S1). The fungal mRNA levels were normalized with respect to the plant glycerinaldehyde-3-phosphate dehydrogenase (GAPDH) mRNA levels. Staining of hyphae and spores was performed with trypan blue $(0.05 \%)$ prior to light microscopy.

\section{Microscopy.}

Samples for light and fluorescence microscopy were prepared according to the method for the cocultivation described above. The lipid dye Nile Red (1,6-diphenyl-1,3,5-hexatriene; Sigma-Aldrich) was employed for fungal staining. A stock solution was produced by solubilizing $1 \mathrm{mg}$ of Nile Red in $1 \mathrm{ml}$ of methanol. Solutions applied contained $1 \mu \mathrm{l}$ of the Nile Red stock solution dissolved in $1 \mathrm{ml}$ of $\mathrm{H}_{2} \mathrm{O}_{\text {dest }}$. Dependent on the size of the testing area, 100 to $500 \mu \mathrm{l}$ of Nile Red solution was applied. For fungus staining Chlorazol black E (Brundrett et al. $1984)$ was used. Chlorazol black $\mathrm{E}(0.03 \% \mathrm{wt} / \mathrm{vol})$ was dissolved 
in $\mathrm{H}_{2} \mathrm{O}_{\text {dest }}$ and was added with equal volumes lactic acid and glycerol. Prior to staining with Chlorazol black E at $90^{\circ} \mathrm{C}$, the roots were cleared in $1 \mathrm{M} \mathrm{KOH}$ at $90^{\circ} \mathrm{C}$. The Arabidopsis roots were imaged using an Axio Imager.M2 (Zeiss Microscopy GmbH) equipped with a $40 \times$ objective (Plan-Apochromat $40 \times / 0.8$ ). The bright field and fluorescence images (absorption $553 \mathrm{~nm}$ ) were recorded with a monochromatic camera (Axiocam 503 mono Zeiss). Digital images were processed with the ZEN software (Zeiss) and were treated with Adobe PhotoShop to optimize brightness, contrast, and coloring and to overlay the photomicrographs.

$\left[\mathrm{Ca}^{2+}\right]_{c y t}$ measurement and mutant screen.

Aequorin-based luminescence measurements were performed using 16-day-old individual $\mathrm{M}_{2}$ plants grown on Hoagland medium (Johnson et al. 2011a; Vadassery and Oelmüller 2009; Vadassery et al. 2009). pMAQ2 plants served as control (Knight et al. 1991). For $\left[\mathrm{Ca}^{2+}\right]_{\text {cyt }}$ measurements, approximately $70 \%$ of the roots per seedling were dissected and were incubated overnight in $150 \mu \mathrm{l}$ of $7.5 \mu \mathrm{M}$ coelentrazine (P.J.K. GmbH) in the dark at $20^{\circ} \mathrm{C}$ in a 96 -well plate (Thermo Fischer Scientific). Bioluminescence counts from roots were recorded as relative light units (RLU) with a microplate luminometer (Luminoskan Ascent, version 2.4, Thermo Electro Corporation). For the induction of the $\mathrm{Ca}^{2+}$ response, the $M$. hyalina preparations, cellotriose (Sigma) or chitohexaose (a chitin polymer) (Megazyme) were used, as described above. The mutant screen was performed with the CWP from M. hyalina; the putative $M_{2}$ mutants were rescued and were transferred to pots containing garden soil and vermiculite at 9:1 (vol/vol) for further screening and validation. The mutant seedlings (called cycam-Mh) were grown in a temperature-controlled growth chamber under a short-day condition (8-h light and 16-h dark cycle; temperature $20 \pm 1^{\circ} \mathrm{C}$; light intensity, $80 \mu \mathrm{mol} \mathrm{m} \mathrm{m}^{-2} \mathrm{~s}^{-1}$ ) for 4 weeks, followed by long-day conditions in Aracon tubes. The seeds were harvested from individual $\mathrm{M}_{3}$ plants and were again screened to obtain homozygote mutants.

\section{Preparation of the $\mathrm{Ca}^{2+}$-inducing fraction \\ from M. hyalina, S. indica, and A. brassicae.}

CWP of M. hyalina (CWP-Mh, which was used for the mutant screen and initial experiments described above), of $S$. indica (CWP-Si), and of A. brassicae (CWP-Ab) were isolated according to Anderson-Prouty and Albersheim (1975) with modifications (Johnson et al. 2011b, 2014; Lee et al. 2011). Mycelia from liquid cultures were harvested by filtration through four layers of nylon membrane (pore size, $70 \mu \mathrm{m}$; Sefar $\mathrm{GmbH}$ ) and were washed five times with sterile $\mathrm{H}_{2} \mathrm{O}$ before homogenization in sterile $\mathrm{H}_{2} \mathrm{O}(1: 5$; wt/vol) with a Waring blender. The slurry was then filtered through four layers of nylon membrane. The residue was collected, was washed again (three times) with sterile $\mathrm{H}_{2} \mathrm{O}$, then twice with chloroform/methanol (1:1), and finally, twice with acetone. The material representing the crude mycelial CWP-Mh was airdried for $2 \mathrm{~h}$ under sterile conditions. The material was suspended in sterile $\mathrm{H}_{2} \mathrm{O}(1: 100 \mathrm{~g} / \mathrm{ml}$, wt/vol), was filtered through four layers of nylon membrane, followed by two layers of Whatman filter paper and, finally, was sterilized by passing it through a $0.22-\mu \mathrm{m}$ filter. The CWP-Mh was then purified by passing it through a reversed phase Supelclean LC-18 SPE cartridge (10-g bed weight, 60-ml volume) (Sigma-Aldrich). The eluting fractions were collected and the active fraction in the void volume identified by $\left[\mathrm{Ca}^{2+}\right]_{\text {cyt }}$ elevation measurements (Johnson et al. 2011b, 2014; Lee et al. 2011).

For further purification of the one or more active compounds in the CWP-Mh, the proteins were removed by precipitation with $80 \%$ methanol and the supernatant was collected after centrifuging at $6,000 \times g$ for 5 min. The supernatant was applied to a Roti-Spin mini column with a molecular weight cutoff of $3 \mathrm{kDa}$ (Roth) and the flow-through was concentrated in a speed vac. Further purification was performed by HPLC with a LC-18-DB column, $25 \mathrm{~cm} \times 4.60 \mathrm{~mm}$ ID (Suppelco), followed by an Asahipak NH2P-50 4E column, $25 \mathrm{~cm} \times 4.6 \mathrm{~mm}$ ID (Schodex). The active fractions were collected by measuring $\left[\mathrm{Ca}^{2+}\right]_{\mathrm{cyt}}$ elevation, were pooled, and were concentrated in a speed vac. Finally, the active fractions were separated using two ultra-performance liquid chromatographic (UPLC) columns, first an Acclaim C18 column, $250 \times 2.1 \mathrm{~mm}, 2.2 \mu \mathrm{m}$ (Dionex), and finally, a C18 phenyl column, $150 \times 2.1 \mathrm{~mm}, 1.7 \mu \mathrm{m}$ (Phenomenex). For all HPLC and UPLC separations, an acetonitrile: water gradient (0 to $100 \%)$ was used as the mobile phase (30-min run) with a flow rate of $1 \mathrm{ml} / \mathrm{min}$ for the HPLC and $0.3 \mathrm{ml} / \mathrm{min}$ for the UPLC column. The final fraction was named the E fraction.

\section{Hormone analyses.}

Hormone analyses were described in detail in Scholz et al. (2015).

\section{Quantitative ROS measurements.}

Quantitative ROS measurement from roots were performed using the Amplex Red hydrogen peroxide/peroxidase assay kit (Molecular Probes, Invitrogen) according to the manufacturer's instructions. Root sections of 2 to $3 \mathrm{~cm}$ in length were incubated in the reaction mixture for $10 \mathrm{~min}$ in the dark at room temperature. The fluorescence intensity was quantified with a fluorescence microplate reader (Tecan Infinite 200 plate reader) with excitation at $540 \mathrm{~nm}$ and emission at $610 \mathrm{~nm}$. The reaction mixture without the molecular probe or without the plant material served as control.

\section{Gene expression analyses}

by quantitative real-time PCR (qRT-PCR).

RNA was isolated from the tissues described above with TRIzol (Fischer Thermo Scientific), according to manufacturer protocol, followed by DNAse treatment. Total RNA was isolated from at least three independent biological experiments if not otherwise stated. RNA $(1 \mu \mathrm{g})$ was reverse-transcribed by use of the Omniscript cDNA synthesis kit (Qiagen). The qRTPCR analysis was conducted in a CFX CONNECT real time detection system (Bio-Rad). The iQ SYBR green supermix (Bio-Rad) was used, according to the manufacturer protocol, in a final volume of $20 \mu \mathrm{l}$. The cycler was programmed to $95^{\circ} \mathrm{C}$ for $3 \mathrm{~min} ; 40$ cycles of $95^{\circ} \mathrm{C}$ for $30 \mathrm{~s}, 57^{\circ} \mathrm{C}$ for $15 \mathrm{~s}, 72^{\circ} \mathrm{C}$ for $30 \mathrm{~s}$; $72^{\circ} \mathrm{C}$ for $10 \mathrm{~min}$; followed by a melting curve program from $55^{\circ} \mathrm{C}$ to $95^{\circ} \mathrm{C}$ in increasing steps of $0.5^{\circ} \mathrm{C}$. All reactions were performed with three technical replicates. The mRNA levels for each cDNA probe were normalized with respect to the plant $G A P D H$ mRNA level. Fold-induction values of target genes were calculated with the $\Delta \Delta C P$ equation (Pfaffl 2001). Primer pairs were designed with the CLC Main Workbench program (Qiagen).

\section{Chlorophyll fluorescence measurements.}

The fitness of WT and cycam- $M h$ seedlings infected with A. brassicae spores at the leaves were quantified with the Fv/Fm fluorescence parameters as described by Maxwell and Johnson (2000) after dark adaptation of the seedlings for $20 \mathrm{~min}$.

\section{Mortality rate after root infection with $A$. brassicae spores.}

WT and cycam-Mh seedlings infected with $A$. brassicae spores at the roots were removed from the petri dishes at the timepoints indicated in the text. The roots were washed one 
time with sterilium solution (lauryl sarcosine 1\%, Clorix cleaner $23 \%$ ) for $1 \mathrm{~min}$ before four rinses with distilled water (4 min each with gentle shaking). The seedlings were then transferred to soil in square pots and the percentages of plants that survived in the greenhouse were determined after 30 days.

\section{ACKNOWLEDGMENTS}

We thank E. Seebald, I. Sherameti, C. Röppischer, and S. Mussbach for their help during the isolation and initial characterization of the cycam-Mh mutant and A. Lehr for her help with extraction of phytohormones. We thank the Deutsche Forschungsgemeinschaft for funding (CRC1127).

\section{LITERATURE CITED}

Akum, F. N., Steinbrenner, J., Biedenkopf, D., Imani, J., and Kogel, K.-H. 2015. The Piriformospora indica effector PIIN_08944 promotes the mutualistic Sebacinalean symbiosis. Front. Plant Sci. 6:906.

Allègre, M., Héloir, M. C., Trouvelot, S., Daire, X., Pugin, A., Wendehenne, D., and Adrian, M. 2009. Are grapevine stomata involved in the elicitorinduced protection against downy mildew? Mol. Plant-Microbe Interact. 22:977-986.

Anderson-Prouty, A. J., and Albersheim, P. 1975. Host-pathogen interactions: VIII. Isolation of a pathogen-synthesized fraction rich in glucan that elicits a defense response in the pathogen's host. Plant Physiol. 56:286-291.

Ansell, P. J., and Young, T. W. K. 1982. Association of Mortierella chlamydospora and Mortierella indohii with plants in culture. Microbios. Lett. 19:193-144.

Bastias, D. A., Martinez-Ghersa, M. A., Ballaré, C. L., Gundel, P. E., and Metrics, P. X. 2016. A chitin deacetylase from the endophytic fungus Pestalotiopsis sp. efficiently inactivates the elicitor activity of chitin oligomers in rice cells. Sci. Rep. 6:38018.

Bedini, E., De Castro, C., Erbs, G., Mangoni, L., Dow, J. M., Newman, M. A., Parrilli, M., and Unverzagt, C. 2005. Structure-dependent modulation of a pathogen response in plants by synthetic O-antigen polysaccharides. J. Am. Chem. Soc. 127:2414-2416.

Benedetti, M., Pontiggia, D., Raggi, S., Cheng, Z., Scaloni, F., Ferrari, S., Ausubel, F. M., Cervone, F., and De Lorenzo, G. 2015. Plant immunity triggered by engineered in vivo release of oligogalacturonides, damageassociated molecular patterns. Proc. Natl. Acad. Sci. U.S.A. 112: 5533-5538

Benfey, P. N., Linstead, P. J., Roberts, K., Schiefelbein, J. W., Hauser, M. T., and Aeschbacher, R. A. 1993. Root development in Arabidopsis: Four mutants with dramatically altered root morphogenesis. Development 119:57-70.

Benny, G. L. 2009. Zygomycetes. http://www.zygomycetes.org.

Bernhardt, C., Zhao, M., Gonzalez, A., Lloyd, A., and Schiefelbein, J. 2005. The bHLH genes GL3 and EGL3 participate in an intercellular regulatory circuit that controls cell patterning in the Arabidopsis root epidermis. Development 132:291-298.

Bonito, G., Reynolds, H., Robeson, M. S., 2nd, Nelson, J., Hodkinson, B. P., Tuskan, G., Schadt, C. W., and Vilgalys, R. 2014. Plant host and soil origin influence fungal and bacterial assemblages in the roots of woody plants. Mol. Ecol. 23:3356-3370.

Broghammer, A., Krusell, L., Blaise, M., Sauer, J., Sullivan, J. T., Maolanon, N., Vinther, M., Lorentzen, A., Madsen, E. B., Jensen, K. J., Roepstorff, P., Thirup, S., Ronson, C. W., Thygesen, M. B., and Stougaard, J. 2012. Legume receptors perceive the rhizobial lipochitin oligosaccharide signal molecules by direct binding. Proc. Natl. Acad. Sci. U.S.A. 109:13859-13864.

Brotman, Y., Landau, U., Cuadros-Inostroza, Á., Tohge, T., Fernie, A. R., Chet, I., Viterbo, A., and Willmitzer, L. 2013. Trichoderma-plant root colonization: Escaping early plant defense responses and activation of the antioxidant machinery for saline stress tolerance. PLoS Pathog. 9: e1003221.

Brundrett, M. C., Piché, Y., and Peterson, R. L. 1984. A new method for observation the morphology of vesicular-arbuscular mycorrhizae. Can J. Bot. 62:2128-2134.

Brutus, A., Sicilia, F., Macone, A., Cervone, F., and De Lorenzo, G. 2010. A domain swap approach reveals a role of the plant wall-associated kinase 1 (WAK1) as a receptor of oligogalacturonides. Proc. Natl. Acad. Sci U.S.A. 107:9452-9457.

Camehl, I., Drzewiecki, C., Vadassery, J., Shahollari, B., Sherameti, I., Forzani, C., Munnik, T., Hirt, H., and Oelmüller, R. 2011. The OXI1 kinase pathway mediates Piriformospora indica-induced growth promotion in Arabidopsis. PLoS Pathog. 7:e1002051.
Camehl, I., Sherameti, I., Venus, Y., Bethke, G., Varma, A., Lee, J., and Oelmüller, R. 2010. Ethylene signalling and ethylene-targeted transcription factors are required to balance beneficial and nonbeneficial traits in the symbiosis between the endophytic fungus Piriformospora indica and Arabidopsis thaliana. New Phytol. 185:1062-1073.

Chen, J., Gutjahr, C., Bleckmann, A., and Dresselhaus, T. 2015. Calcium signaling during reproduction and biotrophic fungal interactions in plants. Mol. Plant 8:595-611.

Cook, D. E., Mesarich, C. H., and Thomma, B. P. 2015. Understanding plant immunity as a surveillance system to detect invasion. Annu. Rev. Phytopathol. 53:541-563.

Dénarié, J., Debellé, F., and Promé, J.-C. 1996. Rhizobium lipochitooligosaccharide nodulation factors: Signaling molecules mediating recognition and morphogenesis. Annu. Rev. Biochem. 65:503-535.

Fernández, I., Merlos, M., López-Ráez, J. A., Martínez-Medina, A., Ferrol, N., Azcón, C., Bonfante, P., Flors, V., and Pozo, M. J. 2014. Defense related phytohormones regulation in arbuscular mycorrhizal symbioses depends on the partner genotypes. J. Chem. Ecol. 40: 791-803.

Fu, Y., Yin, H., Wang, W., Wang, M., Zhang, H., and Zhao, X. 2011. $\beta-1,3$ glucan with different degree of polymerization induced different defense responses in tobacco. Carbohydr. Polym. 86:774-782.

Furbino, L. E., Godinho, V. M., Santiago, I. F., Pellizari, F. M., Alves, T. M., Zani, C. L., Junior, P. A., Romanha, A. J., Carvalho, A. G., Gil, L. H., Rosa, C. A., Minnis, A. M., and Rosa, L. H. 2014. Diversity patterns, ecology and biological activities of fungal communities associated with the endemic macroalgae across the Antarctic peninsula. Microb. Ecol. 67:775-787.

Gams, W. 1977. A key to the species of Mortierella. Persoonia 9:381-391.

García-Sánchez, M., Palma, J. M., Ocampo, J. A., García-Romera, I., and Aranda, E. 2014. Arbuscular mycorrhizal fungi alleviate oxidative stress induced by ADOR and enhance antioxidant responses of tomato plants. J. Plant Physiol. 171:421-428.

Helariutta, Y., Fukaki, H., Wysocka-Diller, J., Nakajima, K., Jung, J., Sena, G., Hauser, M. T., and Benfey, P. N. 2000. The SHORT-ROOT gene controls radial patterning of the Arabidopsis root through radial signaling. Cell 101:555-567.

Ivashuta, S., Liu, J., Liu, J., Lohar, D. P., Haridas, S., Bucciarelli, B., VandenBosch, K. A., Vance, C. P., Harrison, M. J., and Gantt, J. S. 2005. RNA interference identifies a calcium-dependent protein kinase involved in Medicago truncatula root development. Plant Cell 17:2911-2921.

Jacobs, S., Zechmann, B., Molitor, A., Trujillo, M., Petutschnig, E., Lipka, V., Kogel, K. H., and Schäfer, P. 2011. Broad-spectrum suppression of innate immunity is required for colonization of Arabidopsis roots by the fungus Piriformospora indica. Plant Physiol. 156:726-740.

Johnson, J. M., Nongbri, P. L., Sherameti, I., and Oelmüller, R. 2011a. Calcium signaling and cytosolic calcium measurements in plants. Endocyt. Cell Res. 21:64-76.

Johnson, J. M., Reichelt, M., Vadassery, J., Gershenzon, J., and Oelmüller, R. 2014. An Arabidopsis mutant impaired in intracellular calcium elevation is sensitive to biotic and abiotic stress. BMC Plant Biol. 14: 162.

Johnson, J. M., Sherameti, I., Ludwig, A., Nongbri, P. L., Sun, C. 2011b. Protocols for Arabidopsis thaliana and Piriformospora indica cocultivation-A model system to study plant beneficial traits. Endocyt. Cell Res. 21:101-113.

Johnson, J. M., Sherameti, I., Nongbri, P. L., and Oelmüller, R. 2013. Standardized conditions to study beneficial and nonbeneficial traits in the Piriformospora indicalArabidopsis thaliana interaction. Pages 325-343 in: Piriformospora indica: Sebacinales and their Biotechnological Applications. Soil Biology. A. Varma, G. Kost, and R. Oelmüller, eds. Springer, Berlin.

Johnson, J. M., Thürich, J., Petutschnig, E. K., Altschmied, L., Meichsner, D., Sherameti, I., Dindas, J., Mrozinska, A., Paetz, C., Scholz, S. S. Furch, A. C. U., Lipka, V., Hedrich, R., Schneider, B., Svatoš, A., and Oelmüller, R. 2018. A Poly(A) ribonuclease controls the cellotriosebased interaction between Piriformospora indica and its host Arabidopsis. Plant Physiol. 176:2496-2514.

Kloppholz, S., Kuhn, H., and Requena, N. 2011. A secreted fungal effector of Glomus intraradices promotes symbiotic biotrophy. Curr. Biol. 21: 1204-1209.

Knight, M. R., Campbell, A. K., Smith, S. M., and Trewavas, A. J. 1991. Transgenic plant aequorin reports the effects of touch and cold-shock and elicitors on cytoplasmic calcium. Nature 352:524-526.

Kosa, G., Zimmermann, B., Kohler, A., Ekeberg, D., Afseth, N. K. Mounier, J., and Shapaval, V. 2018. High-throughput screening of Mucoromycota fungi for production of low- and high-value lipids. Biotechnol. Biofuels 11:66. 
Lahrmann, U., Ding, Y., Banhara, A., Rath, M., Hajirezaei, M. R. Döhlemann, S., von Wirén, N., Parniske, M., and Zuccaro, A. 2013. Host-related metabolic cues affect colonization strategies of a root endophyte. Proc. Natl. Acad. Sci. U.S.A. 110:13965-13970.

Lakshmanan, V., Castaneda, R., Rudrappa, T., and Bais, H. P. 2013. Root transcriptome analysis of Arabidopsis thaliana exposed to beneficial Bacillus subtilis FB17 rhizobacteria revealed genes for bacterial recruitment and plant defense independent of malate efflux. Planta 238:657-668.

Lee, M. M., and Schiefelbein, J. 1999. WEREWOLF, a MYB-related protein in Arabidopsis, is a position-dependent regulator of epidermal cell patterning. Cell 99:473-483.

Lee, Y. C., Johnson, J. M., Chien, C. T., Sun, C., Cai, D., Lou, B., Oelmüller, R., and Yeh, K. W. 2011. Growth promotion of Chinese cabbage and Arabidopsis by Piriformospora indica is not stimulated by myceliumsynthesized auxin. Mol. Plant-Microbe Interact. 24:421-431.

Limpens, E., van Zeijl, A., and Geurts, R. 2015. Lipochitooligosaccharides modulate plant host immunity to enable endosymbioses. Annu. Rev. Phytopathol. 53:311-334.

Linnemann, G. 1941. Die Mucorineen-Gattung Mortierella coemans. Gustav Fischer, Jena.

Linnemann, G. 1958. Untersuchungen zur Verbreitung und Systematik der Mortierellen. Arch. Mikrobiol. 30:256-267.

Mähönen, A. P., Bishopp, A., Higuchi, M., Nieminen, K. M., Kinoshita, K., Törmäkangas, K., Ikeda, Y., Oka, A., Kakimoto, T., and Helariutta, Y. 2006. Cytokinin signaling and its inhibitor AHP6 regulate cell fate during vascular development. Science 311:94-98.

Maillet, F., Poinsot, V., André, O., Puech-Pagès, V., Haouy, A., Gueunier, M., Cromer, L., Giraudet, D., Formey, D., Niebel, A., Martinez, E. A., Driguez, H., Bécard, G., and Dénarié, J. 2011. Fungal lipochitooligosaccharide symbiotic signals in arbuscular mycorrhiza. Nature 469: 58-63.

Matsuo, M., Johnson, J. M., Hieno, A., Tokizawa, M., Nomoto, M., Tada, Y., Godfrey, R., Obokata, J., Sherameti, I., Yamamoto, Y. Y., Böhmer, F. D., and Oelmüller, R. 2015. High REDOX RESPONSIVE TRANSCRIPTION FACTOR1 levels result in accumulation of reactive oxygen species in Arabidopsis thaliana shoots and roots. Mol. Plant 8:1253-1273.

Maxwell, K., and Johnson, G. N. 2000. Chlorophyll fluorescence-A practical guide. J. Exp. Bot. 51:659-668.

Mayer, Z., Duc, N. H., Sasvári, Z., and Posta, K. 2017. How arbuscular mycorrhizal fungi influence the defense system of sunflower during different abiotic stresses. Acta Biol. Hung. 68:376-387.

Mechri, B., Tekaya, M., Cheheb, H., Attia, F., and Hammami, M. 2015. Accumulation of flavonoids and phenolic compounds in olive tree roots in response to mycorrhizal colonization: A possible mechanism for regulation of defense molecules. J. Plant Physiol. 185:40-43.

Melo, I. S., Santos, S. N., Rosa, L. H., Parma, M. M., Silva, L. J., Queiroz, S. C., and Pellizari, V. H. 2014. Isolation and biological activities of an endophytic Mortierella alpina strain from the Antarctic moss Schistidium antarctici. Extremophiles 18:15-23.

Miyata, K., Kozaki, T., Kouzai, Y., Ozawa, K., Ishii, K., Asamizu, E., Okabe, Y., Umehara, Y., Miyamoto, A., Kobae, Y., Akiyama, K., Kaku, H., Nishizawa, Y., Shibuya, N., and Nakagawa, T. 2014. The bifunctional plant receptor, OsCERK1, regulates both chitin-triggered immunity and arbuscular mycorrhizal symbiosis in rice. Plant Cell Physiol. 55: 1864-1872.

Nagy, L. G., Petkovits, T., Kovács, G. M., Voigt, K., Vágvölgyi, C., and Papp, T. 2011. Where is the unseen fungal diversity hidden? A study of Mortierella reveals a large contribution of reference collections to the identification of fungal environmental sequences. New Phytol. 191: 789-794.

Nakajima, K., Sena, G., Nawy, T., and Benfey, P. N. 2001. Intercellular movement of the putative transcription factor SHR in root patterning. Nature 413:307-311.

Oelmüller, R. 2018. Sensing environmental and developmental signals via cellooligomers. J. Plant Physiol. 229:1-6.

Ohshima, S., Sato, Y., Fujimura, R., Takashima, Y., Hamada, M., Nishizawa, T., Narisawa, K., and Ohta, H. 2016. Mycoavidus cysteinexigens gen. nov., sp. nov., an endohyphal bacterium isolated from a soil isolate of the fungus Mortierella elongata. Int. J. Syst. Evol. Microbiol. 66:2052-2057.

Peškan-Berghöfer, T., Shahollari, B., Giang, P. H., Hehl, S., and Markert, C. 2004. Association of Piriformospora indica with Arabidopsis thaliana roots represents a novel system to study beneficial plant-microbe interactions and involves early plant protein modifications in the endoplasmatic reticulum and at the plasma membrane. Physiol. Plant. 122:465-477.
Pfaffl, M. W. 2001. A new mathematical model for relative quantification in real-time RT-PCR. Nucleic Acids Res. 29:e45.

Pieterse, C. M. J., Zamioudis, C., Berendsen, R. L., Weller, D. M., Van Wees, S. C. M., and Bakker, P. A. H. M. 2014. Induced systemic resistance by beneficial microbes. Annu. Rev. Phytopathol. 52:347-375

Plett, J. M., Daguerre, Y., Wittulsky, S., Vayssières, A., Deveau, A., Melton, S. J., Kohler, A., Morrell-Falvey, J. L., Brun, A., Veneault-Fourrey, C., and Martin, F. 2014a. Effector MiSSP7 of the mutualistic fungus Laccaria bicolor stabilizes the Populus JAZ6 protein and represses jasmonic acid (JA) responsive genes. Proc. Natl. Acad. Sci. U.S.A. 111: 8299-8304

Plett, J. M., Khachane, A., Ouassou, M., Sundberg, B., Kohler, A., and Martin, F. 2014b. Ethylene and jasmonic acid act as negative modulators during mutualistic symbiosis between Laccaria bicolor and Populus roots. New Phytol. 202:270-286.

Polisensky, D. H., and Braam, J. 1996. Cold-shock regulation of the Arabidopsis TCH genes and the effects of modulating intracellular calcium levels. Plant Physiol. 111:1271-1279.

Pozo, M. J., López-Ráez, J. A., Azcón-Aguilar, C., and García-Garrido, J. M. 2015. Phytohormones as integrators of environmental signals in the regulation of mycorrhizal symbioses. New Phytol. 205:1431-1436.

Ranf, S., Gisch, N., Schäffer, M., Illig, T., Westphal, L., Knirel, Y. A., Sánchez-Carballo, P. M., Zähringer, U., Hückelhoven, R., Lee, J., and Scheel, D. 2015. A lectin S-domain receptor kinase mediates lipopolysaccharide sensing in Arabidopsis thaliana. Nat. Immunol. 16: 426-433.

Sakuradani, E. 2010. Advances in the production of various polyunsaturated fatty acids through oleaginous fungus Mortierella alpina breeding. Biosci. Biotechnol. Biochem. 74:908-917.

Sakuradani, E., Ando, A., Ogawa, J., and Shimizu, S. 2009. Improved production of various polyunsaturated fatty acids through filamentous fungus Mortierella alpina breeding. Appl. Microbiol. Biotechnol. 84: $1-10$.

Sakuradani, E., Ando, A., Shimizu, S., and Ogawa, J. 2013. Metabolic engineering for the production of polyunsaturated fatty acids by oleaginous fungus Mortierella alpina 1S-4. J. Biosci. Bioeng. 116:417-422.

Sakuradani, E., and Shimizu, S. 2009. Single cell oil production by Mortierella alpina. J. Biotechnol. 144:31-36.

Sánchez-Vallet, A., Mesters, J. R., and Thomma, B. P. 2015. The battle for chitin recognition in plant-microbe interactions. FEMS Microbiol. Rev. 39:171-183.

Sato, Y., Narisawa, K., Tsuruta, K., Umezu, M., Nishizawa, T., Tanaka, K., Yamaguchi, K., Komatsuzaki, M., and Ohta, H. 2010. Detection of betaproteobacteria inside the mycelium of the fungus Mortierella elongata. Microbes Environ. 25:321-324.

Scholz, S. S., Reichelt, M., Mekonnen, D. W., Ludewig, F., and Mithöfer, A. 2015. Insect herbivory-elicited GABA accumulation in plants is a wound-induced, direct, systemic, and jasmonate-independent defense response. Front. Plant Sci. 6:1128.

Sherameti, I., Venus, Y., Drzewiecki, C., Tripathi, S., Dan, V. M., Nitz, I., Varma, A., Grundler, F. M., and Oelmüller, R. 2008. PYK10, a betaglucosidase located in the endoplasmatic reticulum, is crucial for the beneficial interaction between Arabidopsis thaliana and the endophytic fungus Piriformospora indica. Plant J. 54:428-439.

Silipo, A., Molinaro, A., Sturiale, L., Dow, J. M., Erbs, G., Lanzetta, R., Newman, M. A., and Parrilli, M. 2005. The elicitation of plant innate immunity by lipooligosaccharide of Xanthomonas campestris. J. Biol. Chem. 280:33660-33668.

Song, Y., Chen, D., Lu, K., Sun, Z., and Zeng, R. 2015. Enhanced tomato disease resistance primed by arbuscular mycorrhizal fungus. Front. Plant Sci. 6:786

Souza, C. A., Li, S., Lin, A. Z., Boutrot, F., Grossmann, G., Zipfel, C., and Somerville, S. C. 2017. Cellulose-derived oligomers act as damageassociated molecular patterns and trigger defense-like responses. Plant Physiol. 173:2383-2398.

Spatafora, J. W., Chang, Y., Benny, G. L., Lazarus, K., Smith, M. E., Berbee, M. L., Bonito, G., Corradi, N., Grigoriev, I., Gryganskyi, A., James, T. Y., O’Donnell, K., Roberson, R. W., Taylor, T. N., Uehling, J., Vilgalys, R., White, M. M., and Stajich, J. E. 2016. A phylum-level phylogenetic classification of zygomycete fungi based on genome-scale data. Mycologia 108:1028-1046.

Stein, E., Molitor, A., Kogel, K.-H., and Waller, F. 2008. Systemic resistance in Arabidopsis conferred by the mycorrhizal fungus Piriformospora indica requires jasmonic acid signaling and the cytoplasmic function of NPR1. Plant Cell Physiol. 49:1747-1751.

Tedersoo, L., Bahram, M., Põlme, S., Kõljalg, U., Yorou, N. S., Wijesundera, R., Villarreal Ruiz, L., Vasco-Palacios, A. M., Thu, P. Q., Suija, A., Smith, M. E., Sharp, C., Saluveer, E., Saitta, A., Rosas, 
M., Riit, T., Ratkowsky, D., Pritsch, K., Põldmaa, K., Piepenbring, M., Phosri, C., Peterson, M., Parts, K., Pärtel, K., Otsing, E., Nouhra, E., Njouonkou, A. L., Nilsson, R. H., Morgado, L. N., Mayor, J., May, T. W., Majuakim, L., Lodge, D. J., Lee, S. S., Larsson, K. H., Kohout, P., Hosaka, K., Hiiesalu, I., Henkel, T. W., Harend, H., Guo, L. D., Greslebin, A., Grelet, G., Geml, J., Gates, G., Dunstan, W., Dunk, C., Drenkhan, R., Dearnaley, J., De Kesel, A., Dang, T., Chen, X., Buegger, F., Brearley, F. Q., Bonito, G., Anslan, S., Abell, S., and Abarenkov, K. 2014. Global diversity and geography of soil fungi. Science 346: 1256688 .

Tominaga, R., Iwata, M., Okada, K., and Wada, T. 2007. Functional analysis of the epidermal-specific MYB genes CAPRICE and WEREWOLF in Arabidopsis. Plant Cell 19:2264-2277.

Uehling, J., Gryganskyi, A., Hameed, K., Tschaplinski, T., Misztal, P. K., Wu, S., Desirò, A., Vande Pol, N., Du, Z., Zienkiewicz, A., Zienkiewicz, K., Morin, E., Tisserant, E., Splivallo, R., Hainaut, M., Henrissat, B., Ohm, R., Kuo, A., Yan, J., Lipzen, A., Nolan, M., LaButti, K., Barry, K., Goldstein, A. H., Labbé, J., Schadt, C., Tuskan, G., Grigoriev, I., Martin, F., Vilgalys, R., and Bonito, G. 2017. Comparative genomics of Mortierella elongata and its bacterial endosymbiont Mycoavidus cysteinexigens. Environ. Microbiol. 19:2964-2983.

Vadassery, J., and Oelmüller, R. 2009. Calcium signaling in pathogenic and beneficial plant microbe interactions: What can we learn from the interaction between Piriformospora indica and Arabidopsis thaliana. Plant Signal. Behav. 4:1024-1027.

Vadassery, J., Ranf, S., Drzewiecki, C., Mithöfer, A., Mazars, C., Scheel, D., Lee, J., and Oelmüller, R. 2009. A cell wall extract from the endophytic fungus Piriformospora indica promotes growth of Arabidopsis seedlings and induces intracellular calcium elevation in roots. Plant J. 59:193-206.

Van Wees, S. C., Van der Ent, S., and Pieterse, C. M. 2008. Plant immune responses triggered by beneficial microbes. Curr. Opin. Plant Biol. 11: 443-448.

Verhagen, B. W., Glazebrook, J., Zhu, T., Chang, H. S., van Loon, L. C., and Pieterse, C. M. 2004. The transcriptome of rhizobacteria-induced systemic resistance in Arabidopsis. Mol. Plant-Microbe Interact. 17: 895-908.

Wada, T., Tachibana, T., Shimura, Y., and Okada, K. 1997. Epidermal cell differentiation in Arabidopsis determined by a $M y b$ homolog, $C P C$. Science 277:1113-1116.

Walker, S. A., Viprey, V., and Downie, J. A. 2000. Dissection of nodulation signaling using pea mutants defective for calcium spiking induced by nod factors and chitin oligomers. Proc. Natl. Acad. Sci. U.S.A. 97: 13413-13418.

Wang, E., Schornack, S., Marsh, J. F., Gobbato, E., Schwessinger, B., Eastmond, P., Schultze, M., Kamoun, S., and Oldroyd, G. E. 2012. A common signaling process that promotes mycorrhizal and oomycete colonization of plants. Curr. Biol. 22:2242-2246.

Wang, L., Chen, W., Feng, Y., Ren, Y., Gu, Z., Chen, H., Wang, H., Thomas, M. J., Zhang, B., Berquin, I. M., Li, Y., Wu, J., Zhang, H., Song, Y., Liu, X., Norris, J. S., Wang, S., Du, P., Shen, J., Wang, N., Yang, Y., Wang, W., Feng, L., Ratledge, C., Zhang, H., and Chen, Y. Q. 2011. Genome characterization of the oleaginous fungus Mortierella alpina. PLoS One 6:e28319.

Wang, W., Xie, Z.-P., and Staehelin, C. 2014. Functional analysis of chimeric lysin motif domain receptors mediating Nod factor-induced defense signaling in Arabidopsis thaliana and chitin-induced nodulation signaling in Lotus japonicus. Plant J. 78:56-69.

Weiß, M., Waller, F., Zuccaro, A., and Selosse, M. A. 2016. Sebacinales-One thousand and one interactions with land plants. New Phytol. 211:20-40.

Yang, S., Tang, F., Gao, M., Krishnan, H. B., and Zhu, H. 2010. $R$ gene-controlled host specificity in the legume-rhizobia symbiosis Proc. Natl. Acad. Sci. U.S.A. 107:18735-18740.

Ye, W., and Murata, Y. 2016. Microbe associated molecular pattern signaling in guard cells. Front. Plant Sci. 7:583.

Zamioudis, C., and Pieterse, C. M. 2012. Modulation of host immunity by beneficial microbes. Mol. Plant-Microbe Interact. 25:139-150.

Zhang, H., and Franken, P. 2014. Comparison of systemic and local interactions between the arbuscular mycorrhizal fungus Funneliformis mosseae and the root pathogen Aphanomyces euteiches in Medicago truncatula. Mycorrhiza 24:419-430.

Zhang, H., Lu, D., Li, X., Feng, Y., Cui, Q., and Song, X. 2018. Heavy ion mutagenesis combined with triclosan screening provides a new strategy for improving the arachidonic acid yield in Mortierella alpina. BMC Biotechnol. 18:23.

Zuccaro, A., Lahrmann, U., Güldener, U., Langen, G., Pfiffi, S., Biedenkopf, D., Wong, P., Samans, B., Grimm, C., Basiewicz, M. Murat, C., Martin, F., and Kogel, K. H. 2011. Endophytic life strategies decoded by genome and transcriptome analyses of the mutualistic root symbiont Piriformospora indica. PLoS Pathog. 7:e1002290.

Zycha, H., Siepmann, R., and Linnemann, G. 1969. Mucorales: Eine Beschreibung aller Gattungen und Arten dieser Pilzgruppe. Cramer, Lehre, Germany. 